\title{
Who Improves or Worsens Liquidity in the Korean Treasury Bond Market?
}

\author{
Jieun Lee*
}

The views expressed herein are those of the authors and do not necessarily reflect the official views of the Bank of Korea. When reporting or citing this paper, the authors' names should always be explicitly stated.

* Economist, Micro \& Institutional Economics Team, Economic Research Institute, The Bank of Korea, Tel: +82-2-759-5470, E-mail: jelee@bok.or.kr.

I am grateful for helpful comments and suggestions from Wook Sohn, Hwan-Koo Kang, Hosung Lim at The Bank of Korea, and Prof. Kwanyoung Lee at Chung-Ang University. I also wish to thank the seminar participants at The Bank of Korea. 


\section{Contents}

I . Introduction …………………………………………………. 1

II. Background, Variable Definition, Descriptive Statistics … 7

III. Empirical Model and Regression Results …………... 13

IV. Summary and Concluding Remarks …………………. 39

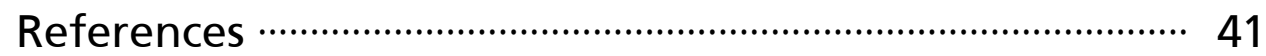

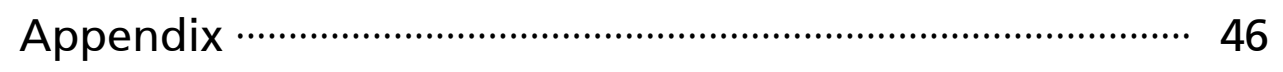




\section{Who Improves or Worsens Liquidity in the Korean Treasury Bond Market?}

This study analyzes how heterogenous institutional investors affect Korean Treasury bond liquidity in the over-the-counter (OTC) market using a unique individual bond-level data set over the period from January 2007 to December 2016. We find that bonds with higher foreign bond holding have a greater price impact of trades and lower trading activities, all indicating lower liquidity. The liquidity-reducing effects of foreign investors are stronger for off-the-runs than on-the-runs and for the post-crisis period (2010-2016) than the crisis period (2007-2009). In contrast, bond holdings by domestic financial investment companies contribute to enhancing liquidity. Furthermore, the effect of bond holdings by domestic banks, insurance companies and pension funds on liquidity varies with issuance maturities.

Keywords: Foreign investors, Institutional investors, Price impact, Investor heterogeneity, Treasury bond liquidity

JEL Classification: G10, G32, G34 


\section{I . Introduction}

The Korean Treasury bond market has been experienced rapid growth thanks to a number of market reforms, increased issuances of treasuries and regulatory changes. In order to build a strong resilience to external shocks and stabilize the financial system, policy makers strove to set up a favorable trading environment, especially for foreign investors, to diversify the investor base and to improve liquidity. In fact, such efforts lead to a substantial increase in foreign bond holdings in Koreal) from 1.69 percent to 10.47 percent over the period from Q1:2007 to Q4:2016. Institutional investors are generally considered as major investors in advanced as well as emerging markets (Khorana, Servae, and Tufano, 2005) and institutional ownership heterogeneity is likely to be associated with different trading strategies in stock markets (e.g., Hoskisson et al., 2002 and Tihanyi et al., 2003). Although the investor base in Korea has widened as the government bond market expanded, we do not know the role of foreign investors or domestic institutional investors in fixed income markets. Consequently, it is important to figure out who contributes to liquidity improvement, as well as who destabilizes financial markets through a sudden withdrawal of their bond holdings.

This paper, therefore, investigates how bond holdings by various types of investors affect liquidity using unique individual bond-level Korean Treasury Bond (KTB) data that enable us to identify the categories of investors. Specifically, we examine how foreign investors and heterogeneous domestic institutional investors-banks, financial investment companies (e.g., security companies, private equity, asset management companies, merchant bank) and insurance companies/pension funds-affect liquidity in the Treasury bond market. Investors with different investment horizons, trading objectives and risk preferences are

1) Foreign bond holdings in local currency (LCY) government bonds is defined as the percentage in LCY government bonds held by foreign investors relative to the amount of LCY government bonds outstanding in a specific market. (source: https://asianbondsonline.adb.org) 
expected to have different impacts on the local financial market.

In fact, liquidity is a key factor in the government bond market. First, we have learned that, in the wake of the global financial crisis, the lack of liquidity appears to have caused high volatility and increased fire sales and capital outflows, and thus expedite the financial crisis (e.g., Beber, Brandt, and Kavajecz, 2009; Brunnermeier and Pedersen, 2009 and Longstaff, 2004). Second, liquidity is one of the main factors in determining Treasury bond prices and yields (e.g., Amihud and Mendelson, 1991; Brandt and Kavajecz, 2004 and Li et al. 2009). Goyenko and Sarkissian (2014), using market-level data from 46 countries over a 34-year period, show that bond illiquidity is a priced factor after controlling for various world- and country-level variables. Third, the yield curve in a liquid bond market is an important channel of macroeconomic news and monetary policy transmission.2) Despite its importance, to our knowledge, none of the previous studies investigate the effect of heterogeneous bond holders on government bond liquidity as we do in this paper.

Little work on the ownership-liquidity relation has been done in the bond market, but the hypotheses, employed mainly in the equity market, can be applicable to those of the government bond market. First, market microstructure studies suggest asymmetric information as a main determinant of liquidity. The adverse selection hypothesis suggests that when informed shareholders possess superior information than other investors, information asymmetry arises, and liquidity is thus reduced (e.g., Easely and O'Hara, 1987; Glosten and Milgrom, 1985; Grossman and Stiglitz, 1980; Kyle, 1985; Rubin, 2007). In particular, market makers widen bid-ask spreads and reduce depth when they have a high probability of trading with informed traders because uninformed traders lose to the informed traders in the stock market (e.g., Copeland and Galai, 1983; Glosten and Milgrom, 1985; Kyle, 1985 and Stoll, 2000).

2) For example, Balduzzi, Elton and Green (2001) and Green (2004), using intraday data, examine the relationship between macroeconomic news and the illiquidity of Treasury bonds. Similarly, Goyenko, Subrahmanyam, and Ukhov (2011) find that the Fed funds rate is one of the main sources of Treasury bond illiquidity. 
Similarly, the hypothesis can be applicable to the Treasury bond market. In fact, government bond prices are mainly influenced by public information, in contrast to stock prices, which are affected by the presence of inside information on a firm's cash flow (e.g., Biais and Green, 2005; Balduzzi, Elton and Green, 2001). Even when only public information is available, information asymmetries appear to arise due to the heterogeneous abilities of interpreting public information (e.g., Green 2004 and Brandt and Kavajecz, 2004), observation of investors' order flow by dealers (Lyons, 2001) or financial networks (Booth, Gurun, and Zhang, 2014).

Second, in the absence of asymmetric information, different types of investors may affect liquidity through order imbalance, infrequent trading and market volatility in the stock as well as the bond markets. For example, Choe et al. (1999) argue that herding behavior by foreign investors may increase order imbalance, consequently reducing liquidity. Brunnermeier and Pedersen (2009) find that if market makers or liquidity providers face capital constraints, excess buying or selling by foreign investors may lead to a reduction in liquidity due to a greater inventory risk. Brockman, Dennis and Chung (2009) show that block ownership adversely affects liquidity since infrequent trading, not the risk of informed trading, contributes to increasing real friction in the stock market. Rhee and Wang (2009) assert that the negative liquidity impact of foreign investors in Indonesia can be explained by their buy-and-hold strategies or infrequent trading together with their informed trading.

Furthermore, heterogeneous investor behaviors are of importance in government bond markets. Models on trading dynamics show the role of information asymmetries. The different trading behavior between informed and uninformed investors provides an interesting insight. For example, informed traders appear to respond more quickly to news and outperform uninformed traders. Yet, it is not clear who informed traders are or how they become informed traders. Some extant studies suggest that foreign investors, relative to domestic investors, may have the advantage of 
obtaining information through a global financial network or of quickly processing information on global financial shocks. For instance, Booth, Gurun and Zhang (2014), using transaction-level Turkish government bond data, show that global financial institutions can more efficiently obtain and process information through their widespread and strategic financial networks that enable them to better access to order flow and thus perform better than local financial institutions. Some hedge funds, broker-dealers and algorithmic traders improve liquidity by competing with market makers or other liquidity providers (e.g., Hendershott, Jones, and Menkveld, 2011). Others argue that mutual funds typically have to trade when exogenous shocks of cash deposits and withdrawals arise as they are committed to providing funds to unit holders on demand and to complying with their stated investment policy. Finally, insurance companies/pension funds tend to trade government bonds more actively than before the global financial crisis in order to search for yields because the crisis led to extremely low rates fueled by quantitative easing, causing a series of problems in treating insolvency. Yet there is little empirical evidence regarding which group is more informed in the government bond market, and the evidence is mixed with respect to the equity market. ${ }^{3)}$

Using the individual bond-level price and transaction data of Korean Treasury bonds provided by the local information terminal Infomax, we shed additional light on these inconsistent results by looking at the effects of institutional bond holding on Treasury bond liquidity in the over-the counter (OTC) market, a market outside the exchange, over the sample period from January 2007 to December 2016.4) Infomax is a unique data set that provides the levels of bond holdings by heterogenous investor groups at the individual bond level. The wide individual bond-level and time-series sample offers an ideal ground for analyzing the link between the trading behavior of heterogenous investors and bond liquidity.

3) Some provide evidence that domestic investors are more informed than foreign investors (e.g., Dahlquist and Robertsson, 2004; Choe, Kho, and Stultz, 2005) while others find the opposite (e.g., Grinblatt and Keloharju, 2000).

4) We obtain qualitatively similar results when using the weekly frequency data. 
Specifically, our study provides answers to the following questions: Are foreign investors informed traders who take liquidity? Does the relation between institutional bond holdings and liquidity vary across different types of institutional investors? Does the relation between institutional bond holdings and liquidity vary with the information environment? These questions are important in terms of financial stability since it can be achieved through the understanding of the drivers that adversely affect liquidity and the monitoring of market liquidity conditions.

For our empirical analyses, we first estimate two liquidity measures that have been widely employed in previous literature (e.g., Diaz and Escribano, 2017): the price impact of trades, measured by the Amihud measure (AMI), and the market trading activities, measured by market share measure (MS). It is noted that the AMI estimates illiquidity while the MS estimates liquidity. The price impact of trades estimates the information content of a trade. If certain types of investors were to trade on superior information, they could exacerbate the adverse selection problem in the government bond market, lower market liquidity and thereby increase transaction costs; A high market share implies more trading activities with lower transaction costs. Consequently, the bond holding-liquidity relationship helps in understanding the roles of the different types of traders in the government bond market.

In order to figure out the relationship between heterogenous investors' bond holdings and Korean Treasury Bond (KTB) liquidity, we conduct a panel data analysis using the fixed effect model. We first investigate the effects of foreign bond holdings on Treasury bond liquidity and find that bonds with higher foreign ownership have greater price impacts of trades and lower market trading activities, all indicating lower liquidity. This result is consistent with the conjecture that foreign investors, who are often professionally operated investment banking houses or funds from the U.S or Europe, are likely to have better information and investment tools than domestic investors in quickly accessing, processing and interpreting new information through their global financial network (e.g., Rhee and Wang, 
2009; Lee and Chung, 2018 and Booth, Gurun, and Zhang, 2014). In addition to the informed trading, their infrequent trading due to buy-and-hold strategies may further reduce liquidity. These effects are most prevalent in 3-year KTBs. The graph shows that their bond holdings in 3-year KTBs, relative to other types of bonds, are quite volatile over the sample period from 2007 to 2016, indicating the possibility of informed trading or frequent trading.

We further investigate the effects of domestic institutional investors on liquidity after classifying them into three groups: banks, financial investment companies and insurance companies/pension funds.5) Among domestic institutional investors, we find that financial investment companies seem to improve liquidity in the Treasury bond market. The bonds with higher ownership by financial investment companies have lower price impacts of trades and higher market shares. We interpretate this as financial investment companies seem to improve liquidity by competing with other liquidity providers. This is consistent with Hedershott, Jones, and Mekveld (2011)'s paper that some hedge funds, broker-dealers and algorithmic traders enhance liquidity. Overall, we find that bondholding by domestic insurance companies/pension funds and banks appear to significantly increase price impacts but decrease market share, indicating deteriorating liquidity. The liquidity effects of insurance companies/pension funds and banks, however, seem to vary with issuance maturities. For example, the liquidity-reducing effects of insurance companies/pension funds and banks are significant only for 5-year KTBs while the liquidity-enhancing effects of banks are significant for 3-year and 10-year KTBs.

We also conduct several robustness checks. For the subsamples, the crisis period (2007-2009) and the post-crisis period (2010-2016), we find that the results are qualitatively similar to our earlier results, but the effects are much stronger in the post-crisis period. We also find that the liquidity-

5) The remaining groups include non-financial corporations, retail investors and the government, which account for a relatively small percentage of the total outstanding shares (less than $5 \%$ ). 
reducing effects by foreign investors and insurance companies/pension funds are especially strong in off-the-runs, not on-the-runs (the most recently issued bonds). The liquidity enhancing effects by banks are strong for the on-the-runs while those of financial investment companies are strong for the off-the-runs. Lastly, the results based on the generalized method of moments (GMM) and pooled OLS with the Newey-West (1987) heteroskedasticity and autocorrelation consistent standard errors are robust to our earlier findings.

The remainder of the paper is organized as follows. Section 2 provides the background of the KTB market, variable measurements and descriptive statistics. Section 3 presents our empirical results. Section 4 concludes the paper.

\section{Background, Variable Definition, Descriptive Statistics}

\section{Korea Treasury Bond Market}

The Korean bond market has two market systems: the KRX Trading System (KTS), a specialized electronic secondary market or the exchange market and OTC market,6) a market outside the exchange. KTBs are mainly traded through the OTC market based on a negotiated transaction. Main market participants are institutional investors, and the trading unit is traditionally 10 billion Korean Won (KRW). In the OTC market, institutional investors trade bonds through financial investment companies that serve as brokers. Registered traders first obtain trading information through online messengers, and once a negotiation about a bond trade through brokers is concluded, they confirm the trade by messenger or phone.

The Korean government and Korea Financial Investment Association

6) The OTC market includes dealers, brokers, and direct search markets, where direct transaction negotiations mainly take place among the counters of financial investment companies. The OTC market in Korea consists of both broker and dealer markets. Bond brokers can be divided into inter-dealer broker or general securities brokers. The ratio of the trading volume in the OTC market to the total trading volume is around 70 percent over the period from 2007 to 2016 . 
(KOFIA) operate 1) a public disclosure system for OTC bond trading details and 2) a bond quotation system to help market participants' price discovery process and increase market transparency. In order to reduce market search costs and improve transparency in the bond market, a public disclosure system for OTC bond trading details has been introduced. In this system, security companies that trade bonds in the OTC market report their trading details to KOFIA within 15 minutes 7 ) of trade completion and KOFIA transfers such details to the market. This system is similar to the Trade Reporting and Compliance Engine (TRACE), the centralized database including all OTC transactions of the US corporate bond markets.

Before the Korean government introduced the primary dealer (PD) system in 1999, widely implemented by OECD countries, the OTC market accounted for over $90 \%$ of all bond trading. After the implementation of the system, PDs have gradually increased their trading in the exchange market with a series of regulatory changes in their market-making activities. PDs have the exclusive right to participate in the primary market, with the market-making obligation to continuously provide the ask/bid prices of the benchmark bonds to the secondary market or the KRX Trading System. To encourage PDs' market-making role, the government evaluates their market-making performance and provides rewards for strong performances. Security companies or banks are selected as PDs when their trading performances exceed a certain level. Transactions of the KTS are completed by the PDs, but those of the OTC market are done by various registered traders. Since PDs, namely, banks and security companies, do not have the obligation to perform market-making activities in the OTC market, dealers do not play a crucial role in the market. The questions are raised, therefore, whether they contribute to enhancing liquidity in the OTC market or act as informed traders who use information from market-making activities (i.e., customers' order flows) for their own trading.

Investors in the OTC market are classified as foreign investors and

7) The reporting time has been 15 minutes since 2004, called the "15-minute" rule. In 1999-2003, it was 30 minutes from the moment of trade conclusion. 
domestic institutional investors. Domestic institutional investors are further divided into banks, financial investment companies, insurance companies/pension funds and others (e.g., government, retail investors and other corporations). Although the government bond markets have been fully open to foreign investors since the Asian financial crisis in the late 1990s, foreign investment was insignificant until 2007. However, with the distortion of the foreign currency market and the low interest rates due to the quantitative easing of advanced countries after the global financial crisis, foreign investment in KTBs took off in full swing in 2008. As of June 2016, their bond holding is 70.4 trillion, equivalent to $13.6 \%$ of total outstanding KTBs (Korea Treasury Bonds, 2016). This rapid growth is owing to the relatively strong fundamentals of the Korean economy, high interest rates compared to other advanced economies and abundant global liquidity. Our dataset does not include more detailed information on foreign investors, but KTBs (2016) show that one of the main investors in KTBs are foreign central banks, which tend to prefer long-term bonds.

\section{Data}

We collect individual bond-level price and quantity data of the OTC KTB market, provided by Infomax over the period from January 2007 to December 2016. The database contains detailed individual security information: bond code, coupon, issuance date, maturity date, bond price (or yield), trading volume, issuance amount, investors' bond holding, and an indicator showing whether the security is on-the-run or off-the-run. It also provides the security level of ownership data classified by five types of investors in the OTC bond market: foreign investors, banks, financial investment companies, insurance companies/pension funds and others.

The bond holding data include the negative value of net purchases. ${ }^{8}$ ) The CBOE market volatility index (VIX) is supplied by Bloomberg. Yield

8) Net purchases or inventory can have a negative value when traders purchase bonds in the primary or KTS markets and sell them in the OTC market. 
curve data, estimated by Fama-Bliss (1987) bootstrap methods, are obtained from the Korea Asset Pricing.9) Most of the macroeconomic variable data (e.g., AAA,AA-,BB-,corporate bond yield, KOSPI index stock return, the 3 -year Treasury bond yield, and foreign exchange rate) are obtained from the Bank of Korea. Our sample includes the 3-, 5-, and 10-year Treasury bonds issued since 2001 .

We exclude the bond data from the sample in the following cases: 1) if the bonds are traded over the presell period, 2) if the bond price is greater than $30,000 \mathrm{KRW}$ or 3) if the number of traded days in a month is more than 10 days.

Table 1 presents information on the sample from the Infomax dataset over the period from January 2007 to December 2016. KTBs are regularly issued with different maturities: 3, 5, 10, 20 and 30 years. 3-, 5-, and 10-year KTBs are newly issued every six months, while 20- and 30-year KTBs are issued once every year. We find that the shorter maturity bonds are more actively traded in the KTB markets.

Table 1. Sample Composition

\begin{tabular}{lllllll} 
& \multicolumn{1}{c}{ 3-year } & \multicolumn{1}{c}{ 5-year } & 10-year & 20-year & 30-year \\
New issues per year & 2 & 2 & 1 & 1 & 1 \\
Outstanding issues & 32 & 37 & 26 & 7 & 3 \\
\# of observations & 3,767 & 6,842 & 8,059 & 2,036 & 363 \\
Avg. volume per day & $2,364.7$ & $1,855.35$ & 675.09 & 199.55 & 374.84 \\
Turnover & $7.2 \%$ & $5.2 \%$ & $2.7 \%$ & & \\
On-the-run & $16.6 \%$ & $9.1 \%$ & $7.7 \%$ & $22.1 \%$ & $58.4 \%$ \\
First-off-the run & $16.7 \%$ & $9.2 \%$ & $7.8 \%$ & $17.5 \%$ & $30.0 \%$ \\
Off-the-run & $66.7 \%$ & $81.7 \%$ & $84.6 \%$ & $60.3 \%$ & $11.6 \%$ \\
\hline
\end{tabular}

Note: This table provides the information on the sample from the Infomax dataset over the sample period from Jan. 2007 to Dec. 2016. Avg. volume per day is the average par trading volume per traded day in billion KRW. Turnover is the ratio of the traded volume (in KRW) to the outstanding amounts. On-the-run is the percentage of the total traded volume of on-the run Treasury bonds. First-off-the run is the percentage of the total traded volume of first-off-the-runs. Off-the-run is the percentage of the total traded volume of off-the-runs.

Source: Infomax

9) http://www.koreaap.com 
In fact, the Korean government has attempted to increase the share of long-term bonds to minimize refinancing risks and repayment burdens. 20and 30-year KTBs started in 2006 and 2012, respectively. In October 2016, the pilot issuance of a 50-year KTB was introduced. Despite these government efforts, the long-term bonds are still sparsely traded with a low number of observations. For our analyses we therefore use the 3-, 5-, and 10-year KTBs, which have been actively traded.

\section{Liquidity Measures}

A liquid market is generally defined as one in which trades can be immediately executed with low costs without a price impact of trades. Since the concept of liquidity is elusive and complicated, no single measure captures these multi-dimensional aspects (i.e., trading cost, price impact, trading speed and depth). Despite these difficulties, there are standardized low-frequency liquidity as well as high-frequency liquidity measures in the stock markets (e.g., Chung and Zhang, 2009; Roll, 1984; Amihud, 1986; Corwin and Shutlz, 2012). In the fixed income market, intraday data on quotes and trades, however, are not generally available because bond trading is mostly executed in the OTC market rather than centralized exchanges. In terms of finding the best measure of liquidity in the corporate bond market, Schestag Schuster and Uhrig-Homburg (2016), using TRACE (U.S OTC corporate bond market) data, find that transaction costs are well captured by most liquidity proxies such as the Corwin and Schultz (2012) measure, the Gibbs (Hasbrouck, 2004) measure and the Roll (1984) measure, while the Amihud (2002) measure among the price impact measures performs well against transaction costs. In the Treasury bond market, a number of papers (e.g., Fleming, 2003; Diaz, Merrick and Navarro,2006; Goyenko, Subramanyam, and Ukhov, 2011; Diaz and Escribano, 2016; Ejsing and Sihvonen, 2009) provide evidence that some of the liquidity measures in the stock market are useful in assessing and tracking Treasury market 
liquidity. Specifically, Diaz and Escribano (2016), Li et al. (2009) and Fleming (2003) suggest that microstructure-based liquidity proxies, which are widely used in both equity and corporate bonds, can also be used in testing liquidity effects in the Treasury bond market. Fleming (2003) and Longstaff (2004) show that the flight-to-liquidity and flight-to-quality phenomena are important factors in explaining Treasury bond prices since investors are willing to pay premiums for safety and liquidity during periods of market turmoil. Li et al. (2009) highlight that government bond pricing has been affected by pervasive market-wide liquidity shocks, which are estimated by microstructure-based liquidity proxies.

Following Diaz and Escribano (2016), we estimate the two measures of Treasury bond liquidity: the Amihud measure (AMI) and the market share measure (MS).

The Amihud (2002) illiquidity measure, which is based on the concept introduced by Kyle (1985), estimates the price impact of a trade in fixed income securities.

$$
A M I_{i, j}=\left[\left|R E T_{i, j}\right| / T V_{i, j}\right] * 10^{9}
$$

where $R E T_{i, j}$ is bond $i$ 's return on day $j$ and $T V_{i, j}$ 's bond $i$ 's trading volume (in KRW) on day $j$. The Amihud measure is one of the most widely used measures of the adverse selection cost encountered by liquidity providers (e.g., Eleswarapu and Venkataraman, 2006; Hasbrouck, 2009) and it is also employed in studies on the Treasury bond market (e.g., Booth, Gurun, Zhang, 2014; Diaz and Escribano, 2016). Lee and Chung (2018) assert that the price impact of trades is a similar concept with the adverse selection component of the bid-ask spread in that both measure the information contents of a trade. A higher Amihud measure implies greater price impacts or costs of trading, indicating illiquidity.

The market share measure $\left(\mathrm{MS}_{\mathrm{i}, \mathrm{j}}\right)$ is computed by dividing the individual trading volume for bond $i$ by the total trading volume in the 
government bond market on a given day $j$. A high MS indicates more trading activities with lower transaction costs. Diaz and Escribano (2017) use this measure as a proxy for trading activities, and Diaz, Merrick and Navarro (2005) also employ it to estimate the bond liquidity life cycle.

It is important to note that the AMI is a proxy for illiquidity whereas the MS is a proxy for liquidity. For the empirical analyses, we winsorize the AMI at $2 \%$ and the MS at $1 \%$ and then calculate the monthly average for a daily series of two measures.

\section{Empirical Model and Regression Results}

\section{Preliminary Results}

Panels A and B of Table 2 provide information on liquidity and bond holdings by different types of investors. For our empirical analyses, we use two liquidity measures, $\log$ of AMI and $\log$ of MS. Panel B shows that $\log$ of AMI in 3-year KTBs has a lower value than that of the 10-year KTBs, indicating that short-term bonds have better liquidity than long-term bonds. Log of MS in 3-year KTBs has a higher value than that of 10-year KTBs, indicating that the former more actively traded than the latter.

\section{Table 2. Descriptive Statistics}

Panel A. All Korean Treasury Bonds (KTBs)

\begin{tabular}{llcrcc}
\multicolumn{1}{c}{ Variable } & Obs & Mean & Std. Dev. & Min & Max \\
log(AMI) & 3,288 & -5.753 & 2.676 & -10.336 & 0.433 \\
$\log (\mathrm{MS})$ & 3,288 & -4.300 & 1.417 & -7.842 & -1.260 \\
FOREIGNER(\%) & 3,242 & 15.536 & 13.977 & -11.103 & 79.918 \\
INS\&PEN(\%) & 3,244 & 34.867 & 19.699 & -8.868 & 83.854 \\
FI(\%) & 3,244 & 6.783 & 10.343 & -63.384 & 55.799 \\
BANK(\%) & 3,244 & 2.956 & 19.467 & -57.263 & 69.752 \\
\hline
\end{tabular}


Panel B. Types of KTBs

\begin{tabular}{lrrrrrr}
\multicolumn{1}{c}{ Bond type } & \multicolumn{2}{c}{$3-$ Year } & \multicolumn{2}{c}{$5-$ Year } & \multicolumn{2}{c}{$10-$ Year } \\
\multicolumn{1}{c}{ Variable } & Mean & Std. Dev. & Mean & Std. Dev. & Mean & Std. Dev. \\
log(AMI) & -7.179 & 2.405 & -6.266 & 2.500 & -4.390 & 2.550 \\
log(MS) & -3.587 & 1.156 & -4.054 & 1.349 & -4.937 & 1.350 \\
FOREIGNER(\%) & 29.692 & 20.507 & 13.573 & 8.640 & 9.685 & 6.431 \\
INS\&PEN (\%) & 9.217 & 6.917 & 30.351 & 10.369 & 53.307 & 11.173 \\
FI(\%) & 9.452 & 16.272 & 8.313 & 9.020 & 3.840 & 5.521 \\
BANK(\%) & 21.434 & 17.028 & 6.753 & 15.229 & -10.851 & 13.347 \\
\hline
\end{tabular}

Note: AMI is the price impact of trades, referring to Amihud (2002); MS is the market share, which is the ratio of the individual trading volume to the total trading volume in the whole market; FOREIGNER is the ratio of the number of bonds held by foreign investors in the OTC market to the total number of bonds outstanding; INS\&PEN is the ratio of the number of bonds held by insurance companies and pension funds in the OTC market to the total number of bonds outstanding; $\mathrm{FI}$ is the ratio of the number of bonds held by financial investment companies in the OTC market to the total number of bonds outstanding; BANK is the ratio of the number of bonds held by banks in the OTC market to the total number of bonds outstanding.

Source: Infomax

This evidence is consistent with previous findings that short-term bonds have a lower liquidity risk than long-term bonds. Additionally, Table 2 provides the distributions of different types of investors. For the whole sample, $35 \%$ of KTBs' outstanding shares are held by insurance companies/pension funds, $16 \%$ by foreign investors, and $7 \%$ by financial investment companies. In Panel B we construct the sub-sample based on bond maturity. We find that foreign investors hold 30\% for 3-year KTBs, $14 \%$ for 5 -year KTBs, and $10 \%$ for 10 -year KTBs, indicating that they have a strong preference for short-term relative to long-term bonds in spite of their significant amount of long-term bond holdings. Insurance companies/ pension funds hold $30 \%$ for 5 -year KTBs and $53 \%$ for 10 -year KTBs, showing their strong preference for long-term bonds, related with the matching of asset and liabilities. Financial investment companies hold $9.5 \%$ for 3-year KTBs, $8.3 \%$ for 5-year KTBs and $3.8 \%$ for 10-year KTBs, suggesting that they prefer short-term bonds to long-term bonds. 
Figure 1. Time Series of Korean Treasury Bond Liquidity

Panel A. Amihud Measure

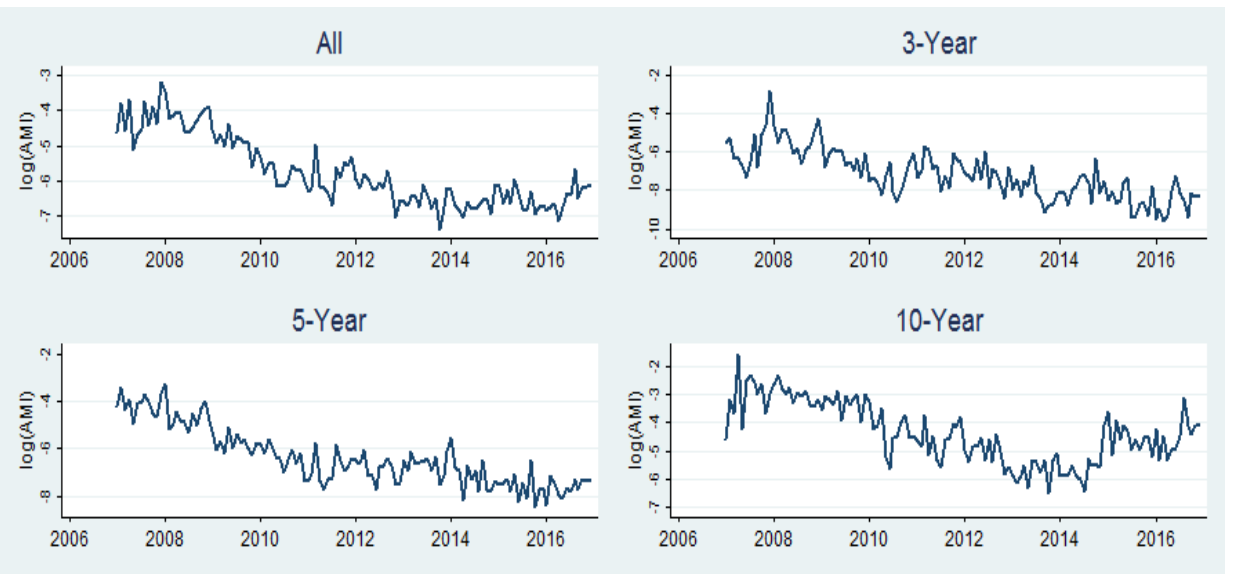

Panel B. MS Measure
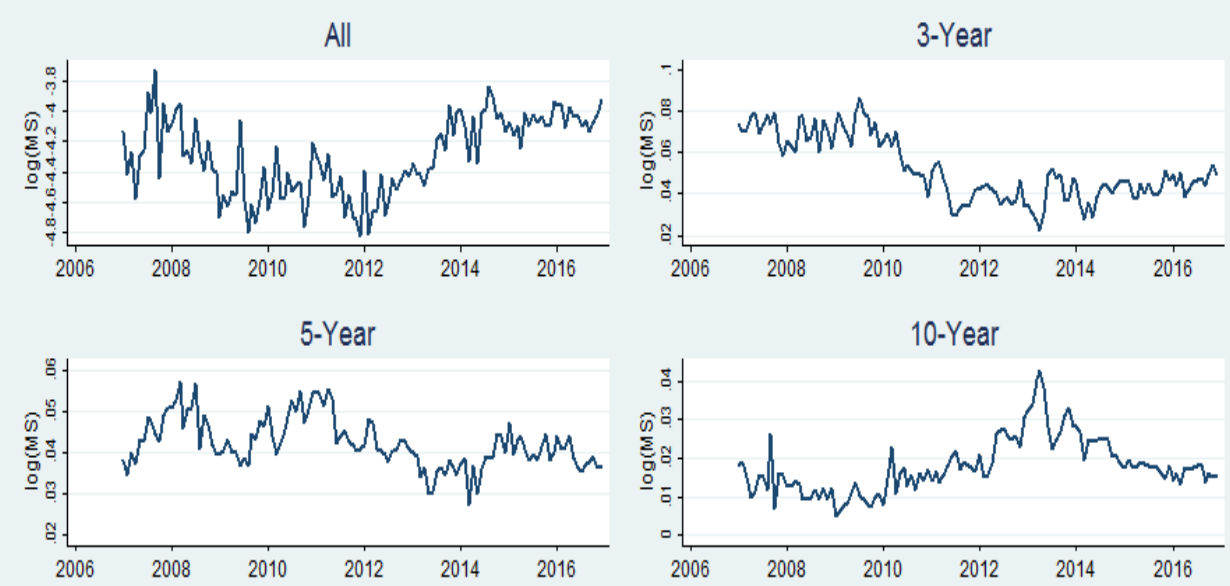

Note: This figure plots the monthly liquidity of all, 3-, 5-, and 10-year Korean Treasury bonds (KTBs) from January 2007 to December 2016. Panels A and B show the trend of liquidity measure, the Amihud measure (AMI) and the market share (MS), respectively. Log transformations are applied for the measures.

Banks hold 21\% for 3-year KTBs, $7 \%$ for 5 -year KTBs and $-11 \%$ for 10-year KTBs, suggesting that banks tend to hold short-term bonds while curtail their long-term bond holdings with a negative value indicating deleveraging or selling bonds. This is consistent with evidence 
in CFGS (2016) that banks in many countries have reduced trading-related exposures in the bond markets due to their reduced risk tolerance and profits, stronger bank regulations and the global financial crisis.

Figure 1 provides the time-series average of $\log$ of AMI and $\log$ of MS for all bonds and 3-, 5-, 10-year KTBs, respectively. In Panel A, we plot the time evolution of the monthly average of the AMI over time. Regardless of bond types, we find that the AMI has the highest value or the lowest liquidity around the global financial crisis (2008 2009); and afterward liquidity has been improved in all bonds except 10-year KTBs. For 10-year KTBs, the price impacts of trades increase over the period from 2014 to 2016. In Panel B the market shares of 3- and 5-year KTBs increased from 2007 to 2011 but began to decrease afterward with small variations; meanwhile, the market share of 10-year KTBs has gradually increased since the global financial crisis in 2009, reaching a peak between 2012 and 2014, and then falling afterward. An increase in the market share of 10-year KTBs appears to be related with government policies aiming to encourage demand for long-term bonds by strengthening the market-making role of PDs for 10-year or longer KTBs.

Panel A of Figure 2 shows the time-series averages of bond holdings by different types of investors in the OTC market: foreign investors on average have gradually increased their bond holdings while temporarily withdrawing bond holdings during the global financial crisis (2008 2009); insurance and pension funds do not change their position quite often, maintaining the high level of bond holdings, about 40 percent; financial investment companies have increased their bond holdings in the post-crisis period; and banks appear to have been deleveraged in the OTC market over the sample period. 
Figure 2. Korean Treasury Bond Holding by Different Types of Investors

Panel A. All KTB Holdings by Different Types of Investors
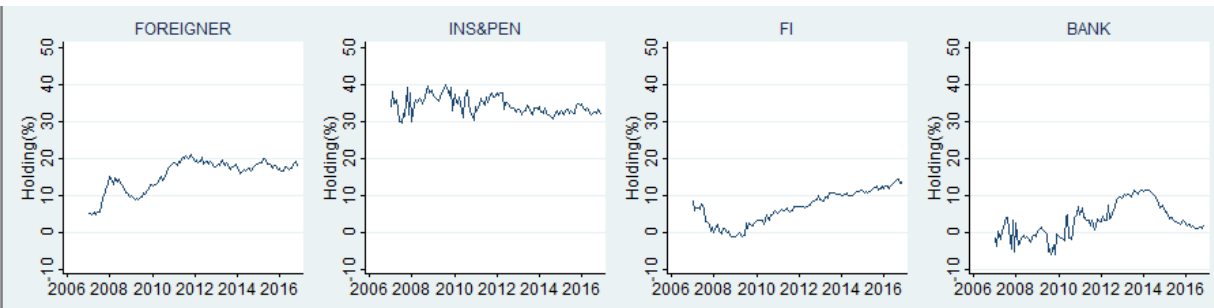

Panel B. 3-year KTB Holdings by Different Types of Investors
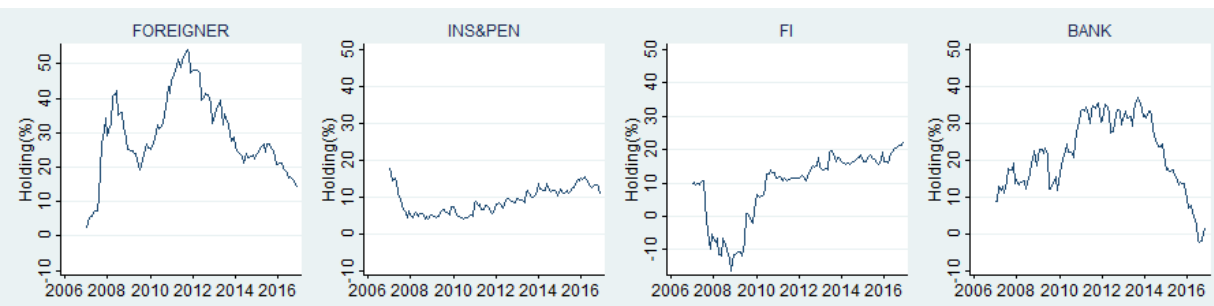

Panel C. 5-year KTB Holdings by Different Types of Investors
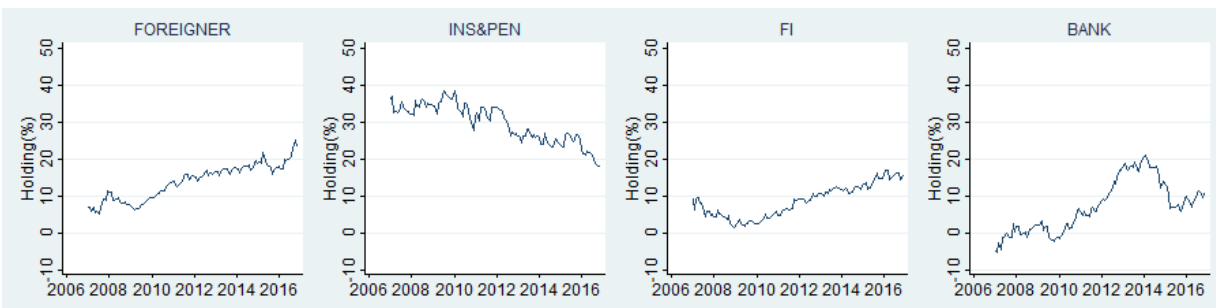

Panel D. 10-year KTB Holdings by Different Types of Investors
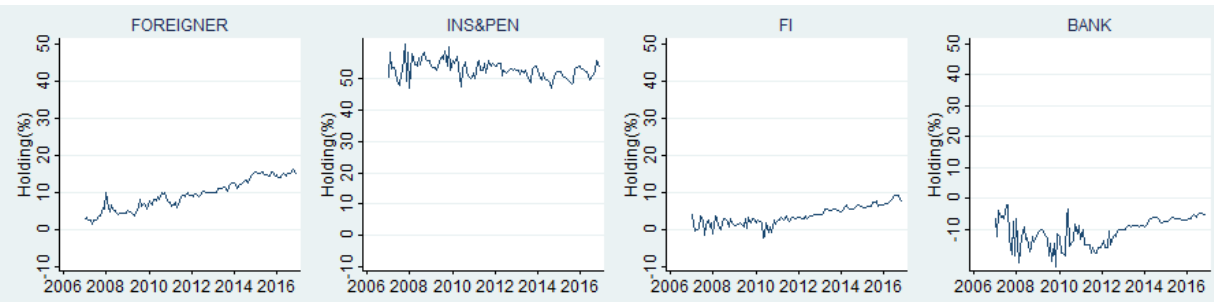

Note: This figure shows the average percentage of shares held by four types of foreign and domestic institutional investors for Korean Treasury Bonds (KTBs) from January 2007 to December 2016. The investor types are (1) foreign investors (FOREIGNER), (2) insurance companies and pension funds (INS\&PEN), (3) financial investment companies (FI) and (4) banks (BANK). 
Interestingly, we find that the trends of bond holdings by various institutional investors are quite different depending on the bond type, indicating that they appear to have different trading strategies, objectives and risk preferences. Panels B, C, and D show the time-series averages of 3-, 5- and 10-year KTB bond holdings by different types of investors over the period from January 2007 to December 2016. Foreign investors seem to trade actively short-term bonds (3-year KTBs), implying that their frequent trading may cause high volatility, but they gradually increase their holdings in long-term bonds (5- and 10-year KTBs). As expected, insurance companies/pension funds prefer to hold long-term bonds, and the level of their holdings is quite persistent over the sample period. Financial investment companies seem to respond sensitively to market conditions because their level of bond holdings is quite volatile, especially for short-term bonds. Banks appear to invest in short-term bonds (3- or 5- KTBs), but they appear to withdraw the bond holding of 10-year KTBs.

Panel A of Figure 3 presents the time series average of on-the-run and off-the-run liquidity. Ample evidence has documented that off/on-the-run yield differentials can be explained by liquidity (e.g., Amihud and Mendelson, 1986; Goldreich, Hanke, and Nath, 2005; Pasquariello and Vega, 2009). Consistent with previous studies that on-the-runs are more actively traded than off-the-runs, the figure shows that on-the-runs have lower price impacts and higher market shares than off-the-runs, indicating high on-the-run liquidity.

Panel B of Figure 3 shows how heterogeneous investors have constructed their portfolios between on-the-runs and off-the-runs over time. The figure shows that heterogeneous investors hold a different proportion between the on-the-runs and off-the-runs. Foreign investors and banks tend to increase their investment in off-the-runs rather than on-the-runs since 2010 while financial investment companies prefer on-the-runs to off-the-runs over the entire period. Insurance companies/pension funds, which generally invest in long-term bonds, seem to hold off-the-runs. 
Figure 3. On-the-run vs. Off-the-run

Panel A. Liquidity Measures

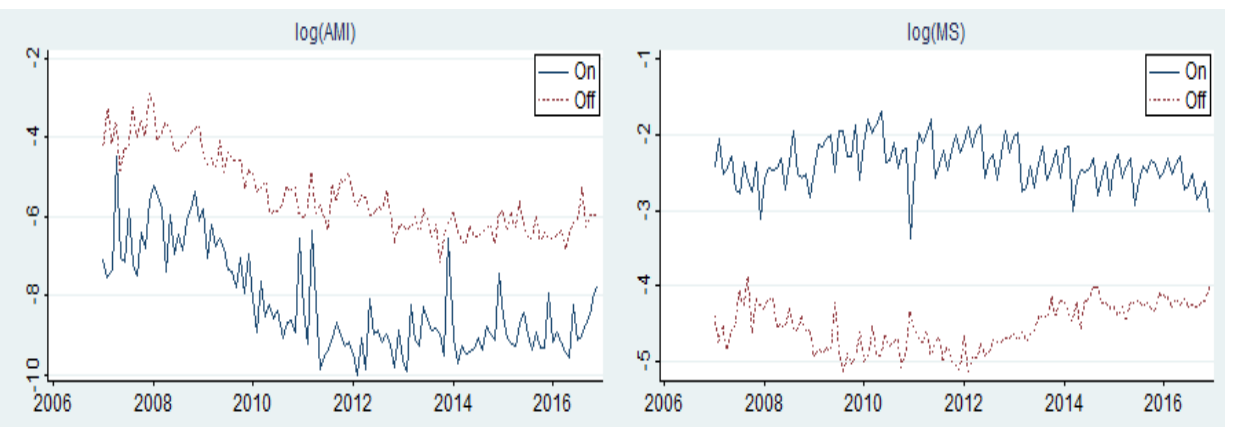

Panel B. Bond Holdings by Different Types of Investors

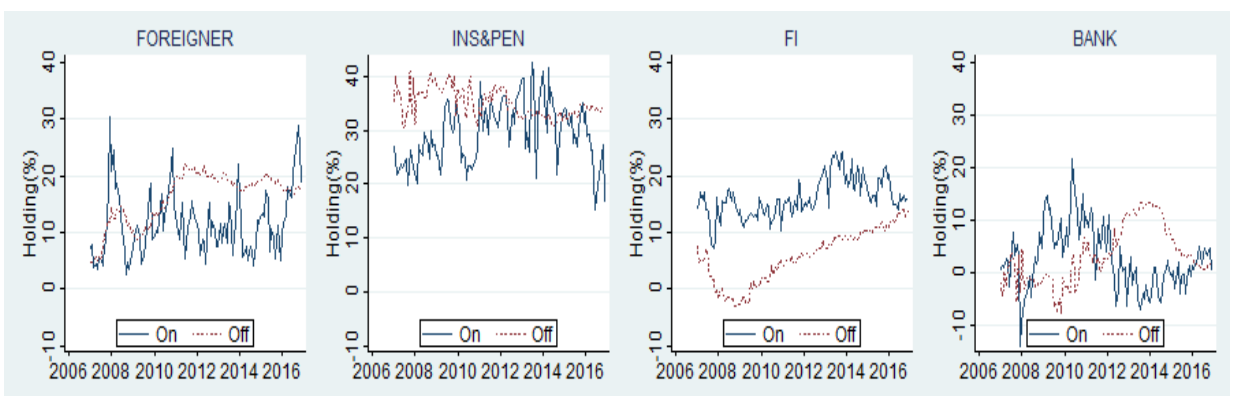

Note: This figure shows the trend of liquidity and averaged bond holdings by different types of investors from January 2007 to December 2016. Panel A shows the trend of liquidity measure, the Amihud measure (AMI) and the market share (MS), respectively. Panel B shows the trend of bond holding by foreigners (FOREIGNER), insurance companies/pension funds (INS\&PEN), financial investment companies (FI) and banks (BANK). 


\section{Baseline Regression Model}

To investigate the relationship between investor base and KTB liquidity, we employ the following baseline regression model with bond fixed effects: ${ }^{10}$ )

$$
\begin{aligned}
L_{I} Q_{i t} & =\beta_{1} \text { FOREIGNER }_{i t-1}+\beta_{2} \text { INS\& PEN }_{i t-1}+\beta_{3} \text { FI }_{i t-1}+\beta_{4} B A N K_{i t-1} \\
& =\sum_{j} \delta_{j} \text { Bond control }_{i t}+\sum_{j} \gamma_{j} \text { Macrocontrol }_{t}+\epsilon_{i t}
\end{aligned}
$$

where $\mathrm{LIQ}_{\mathrm{it}}$ is our dependent variable, liquidity measure in bond $\mathrm{i}$ at month $\mathrm{t}$, which includes the $\log$ transformation of the $\mathrm{AMI}_{\mathrm{it}}$ and $\mathrm{MS}_{\mathrm{it}}$, respectively: $\mathrm{AMI}_{\mathrm{it}}$ is the price impact of trades, referring to Amihud(2002), and $\mathrm{MS}_{\mathrm{it}}$ is the market share, which is the ratio of the individual trading volume to the total trading volume in the whole market. ${ }^{11)}$

The main explanatory variable is bond holdings by investor types for bond $\mathrm{i}$ at month $\mathrm{t}-1$. In this model setting, one of the main concerns is an endogeneity problem that may arise as a result of reverse causality associated with investors' preference for liquid securities. To mitigate the problem, we use a one-period lagged investors' bondholding variable. In particular, we measure security i's foreign bond holdings in month $t-1$ $\left(\right.$ FOREIGNER $\left._{\mathrm{it}-1}\right)$ which is the ratio of the number of bonds held by foreign investors in the OTC market to the total number of bonds outstanding. ${ }^{12)}$ To isolate the effect of foreign bond holdings from its

10) Based on the Hausman test, the null-hypothesis that the unique errors are not correlated with the regressor is rejected, suggesting that the fixed effect model is more appropriate than the random effect model for this study.

11) As alternative measures of trading activity, we use two liquidity proxies, $\mathrm{PVOL}(\mathrm{KRW})$ and turnover: PVOLi,t is the monthly cumulative traded volume (in KRW) and TURNOV is the monthly traded volume divided by the number of bonds outstanding at the end of month. Although the results are not reported, we confirm that the results using the two proxies are qualitatively similar to those using the market share. We also compute the proportion of the bid-ask spread from Bloomberg (Price source: BGN) as an alternative liquidity measure and investigate the relationship between ownership and liquidity. The results of the spread are qualitatively similar to those of the AMI.

12) In the unreported results, we find that the relationship between the changes in foreign bondholding and illiquidity is insignificant. 
domestic counterparty, bond holdings by banks ( $\left.\mathrm{BANK}_{\mathrm{it}-1}\right)$, financial investment companies $\left(\mathrm{FI}_{\mathrm{it}-1}\right)$, and insurance companies/pension funds (INS\&PEN $\mathrm{it}_{\mathrm{it}}$ ) are computed in much the same way as foreign bond holdings.

Referring to Diaz and Escribano (2017), we choose control variables that are highly correlated with bond liquidity. Individual bond characteristic variables are included: BONDRET $_{i t}$ is the average bond return; $\mathrm{AGE}_{\mathrm{it}}$ is the age of bond $i$ in month $t$; LOG(OUTSHR) it is the log of the amount of outstanding shares; $\mathrm{ON}_{\mathrm{it}}$ is the dummy variable that takes value one if the status of the bond is on-the-run. Macroeconomic variables are included: the credit spread between the BB-corporate bond yield and AA-yield (CREDIT RISK $)_{\mathrm{t}}$; stock market return using the KOSPI Index (STKRET $)_{\mathrm{t}}$ ); the CBOE market volatility index (VIX $\mathrm{t}_{\mathrm{t}}$ ), called as fear index; the proxy for flights-to-liquidity and flights-to-quality, computed by the spread between AAA yield and the 3-year Treasury bond yield (AAA-T3); the proxy for capital inflow and outflows, computed as the difference the 5-year KTB yield and the 5-year U.S Treasury bond yield(T5KO-T5US); the foreign exchange rate $\left(\right.$ FXRATE $\left._{\mathrm{t}}\right)$ and the policy rate (BASERATE $\left.\mathrm{t}\right)$. Additionally, we control for the shape of the yield curve: the 3-year Treasury yield (LEVEL $\mathrm{L}_{\mathrm{t}}$; the difference between the $7-$ and the 3-year Treasury yields $\left(\mathrm{SLOPE}_{\mathrm{t}}\right)$; and the difference between the 5-year Treasury yield and the average difference between the 7 - and 3-year Treasury yields $\left(\right.$ CURVARTURE $\left._{\mathrm{t}}\right) . \varepsilon_{\mathrm{t}, \mathrm{t}}$ is the error term. For all regression models, we include time dummies and use robust standard error clustered by bond to control for possible unobserved heterogeneity among bonds. Reported in parentheses are the t-statistics.

This study selects fixed effect models as our main panel regression models. For instance, Roodman (2006) asserts that fixed effect models are more appropriate than GMM for lengthy time periods because the dynamic panel biases become smaller and the number of instruments increases significantly as time $\mathrm{T}$ increases. Judson and Owen (1999) also recommend 
fixed effect models when time $\mathrm{T}$ is greater than 30. Although the results are not reported, this paper, using a Hausman test (1978), confirms that fixed effect models are more appropriate than random effect models.

Panel A of Table 3 shows the results for bond fixed effects with clustered standard errors at the bond-level, estimated from 3,095 bond-month observations including all bonds. Columns (1) through (8) report the results after controlling for bond characteristics, macroeconomic variables and yearly dummies. Our discussion focuses on the results using liquidity as the dependent variable. The price impact of trades is measured by the LOG(AMI) and the market trading activity is measured by the LOG(MS).

Columns (1) and (2) show the relationship between foreign bond holdings and Treasury bond liquidity. In column (1), when using the LOG(AMI) as a dependent variable, the coefficient on foreign bond holding (FOREIGNER) is positive and significant; meanwhile, in column (2), when using the LOG(MS), the coefficient on FOREIGNER is negative and significant. The results indicate that foreign investors are more informed than domestic investors, consuming Treasury bond liquidity. This evidence is consistent with the view that foreign investors are generally better informed than domestic investors and their trading leads to great adverse selection risks to liquidity providers. Prior studies show that foreign investors are more informed than domestic traders in emerging economies because they have more trading experience as well as superior skills in analyzing as well as collecting information (e.g., Lee and Chung, 2018; Rhee and Wang, 2009; Grinblatt and Keloharju, 2000 and Froot, O'Connell, and Seasholes, 2001). While informed investors in stock markets may possess inside or private information on a firm's future cash flow, those in government bond markets may have a superior ability of interpreting public information or have better strategic financial networks than uninformed traders (e.g., Booth, Gurun, and Zhang, 2014).

Columns (3) through (8) show the relationship between different types of domestic investors and liquidity. The coefficients on INS\&PEN and bank 
are positive when the dependent variable is LOG(AMI), but negative when the dependent variable is LOG(MS), which indicates that bond holdings by insurance companies/pension funds and banks lead to increase the price impact of trades while reducing the market share, all indicating lower liquidity (columns (3),(4),(7) and (8)).

Meanwhile, we find the bond holdings by financial investment companies tend to improve liquidity in the KTB market. The coefficients on FI are negative when the dependent variable is LOG(AMI), but positive when the dependent variable is $\operatorname{LOG}(\mathrm{MS})$, which indicates that bond holdings by financial investment companies contribute to reducing the price impact of trades while increasing the market share. This result suggests that financial investment companies seem to improve liquidity through the competition with other liquidity providers.

Panel B of Table 3 show the results of including bond holdings by all types of investors - foreign investors, insurance companies/pension funds, financial investment companies and banks - together with other control variables. Columns (1) and (2) report the results after controlling for bond characteristics, macroeconomic variables and yearly dummies, whereas columns (3) and (4) show the results after controlling for bond characteristics and monthly dummies. 


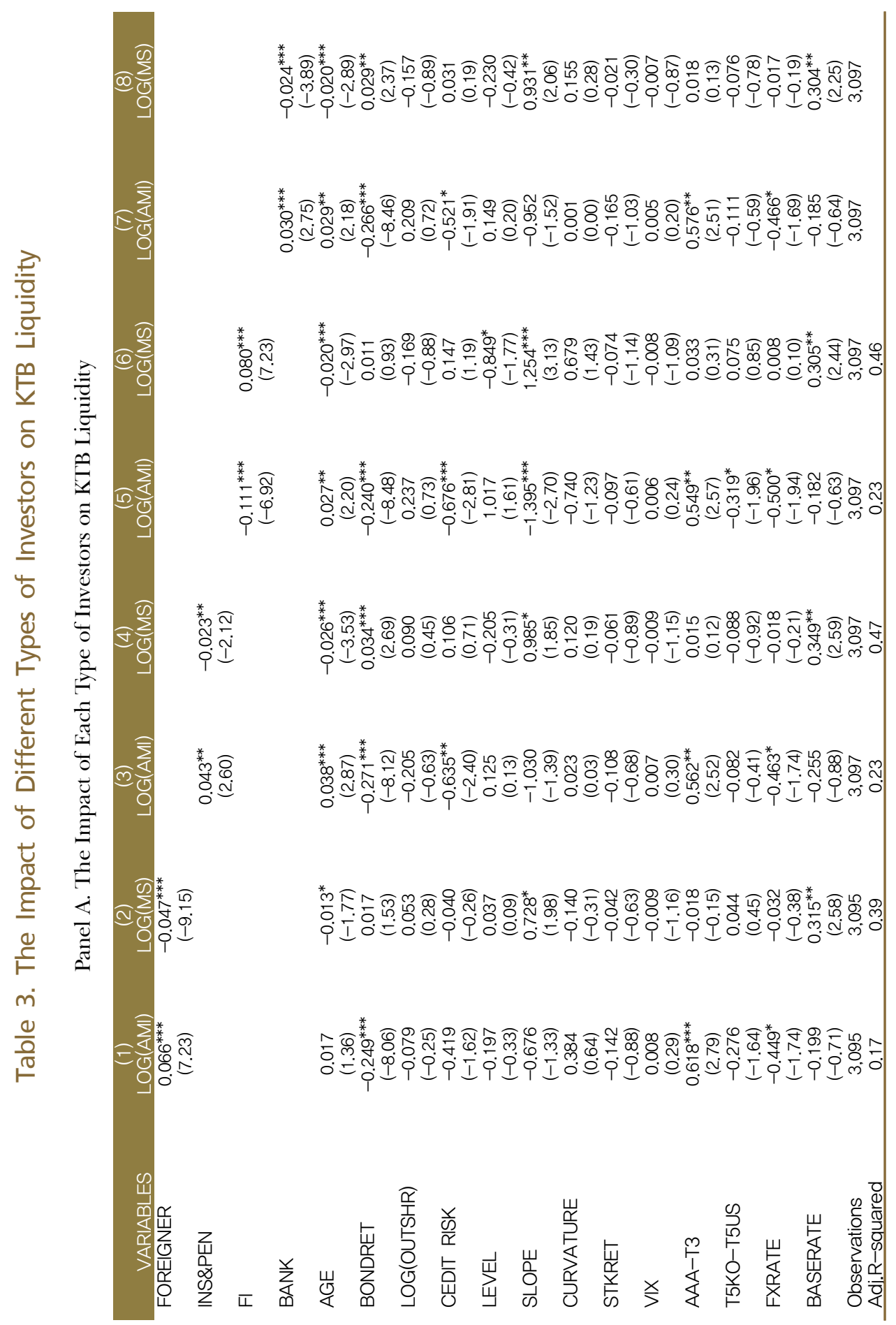


Panel B. The Impact of Different Types of Investors on KTB Liquidity

\begin{tabular}{|c|c|c|c|c|}
\hline VARIABLES & $\begin{array}{c}(1) \\
\text { LOG(AMI) }\end{array}$ & $\begin{array}{c}(2) \\
\text { LOG(MS) }\end{array}$ & $\begin{array}{c}\text { (3) } \\
\text { LOG(AMI) }\end{array}$ & $\begin{array}{c}(4) \\
\text { LOG(MS) }\end{array}$ \\
\hline FOREIGNER & $\begin{array}{c}0.040^{* * *} \\
(4.07)\end{array}$ & $\begin{array}{c}-0.025^{* * *} \\
(-3.69)\end{array}$ & $\begin{array}{c}0.038^{* * *} \\
(3.87)\end{array}$ & $\begin{array}{c}-0.024^{* * *} \\
(-3.55)\end{array}$ \\
\hline INS\&PEN & $\begin{array}{c}0.059^{* * *} \\
(3.32)\end{array}$ & $\begin{array}{c}-0.034^{* * *} \\
(-3.41)\end{array}$ & $\begin{array}{c}0.062^{* * *} \\
(3.41)\end{array}$ & $\begin{array}{c}-0.034^{* * *} \\
(-3.32)\end{array}$ \\
\hline $\mathrm{FI}$ & $\begin{array}{c}-0.069^{* * *} \\
(-4.09)\end{array}$ & $\begin{array}{c}0.053^{* * *} \\
(4.54)\end{array}$ & $\begin{array}{c}-0.073^{* * *} \\
(-4.23)\end{array}$ & $\begin{array}{c}0.055^{* * *} \\
(4.52)\end{array}$ \\
\hline BANK & $\begin{array}{l}0.016 \\
(1.26)\end{array}$ & $\begin{array}{c}-0.013^{*} \\
(-1.87)\end{array}$ & $\begin{array}{l}0.019 \\
(1.42)\end{array}$ & $\begin{array}{c}-0.016^{* *} \\
(-2.06)\end{array}$ \\
\hline AGE & $\begin{array}{c}0.029^{* *} \\
(2.34)\end{array}$ & $\begin{array}{c}-0.020^{* * *} \\
(-3.09)\end{array}$ & $\begin{array}{l}0.245 \\
(0.58)\end{array}$ & $\begin{array}{l}0.026 \\
(0.26)\end{array}$ \\
\hline BONDRET & $\begin{array}{c}-0.228^{* * *} \\
(-8.13)\end{array}$ & $\begin{array}{l}0.003 \\
(0.26)\end{array}$ & $\begin{array}{c}-0.239^{* * *} \\
(-6.14)\end{array}$ & $\begin{array}{l}-0.012 \\
(-0.85)\end{array}$ \\
\hline LOG(OUTSHR) & $\begin{array}{l}-0.366 \\
(-1.11)\end{array}$ & $\begin{array}{l}0.167 \\
(0.85)\end{array}$ & $\begin{array}{l}-0.422 \\
(-1.21)\end{array}$ & $\begin{array}{l}0.196 \\
(0.96)\end{array}$ \\
\hline CEDIT RISK & $\begin{array}{c}-0.625^{* *} \\
(-2.57)\end{array}$ & $\begin{array}{l}0.102 \\
(0.84)\end{array}$ & & \\
\hline LEVEL & $\begin{array}{l}0.571 \\
(0.86)\end{array}$ & $\begin{array}{l}-0.556 \\
(-1.14)\end{array}$ & & \\
\hline SLOPE & $\begin{array}{c}-1.093^{* *} \\
(-2.13)\end{array}$ & $\begin{array}{c}1.048^{* *} \\
(2.64)\end{array}$ & & \\
\hline CURVATURE & $\begin{array}{l}-0.402 \\
(-0.64)\end{array}$ & $\begin{array}{l}0.457 \\
(0.96)\end{array}$ & & \\
\hline STKRET & $\begin{array}{l}-0.108 \\
(-0.68)\end{array}$ & $\begin{array}{l}-0.064 \\
(-0.98)\end{array}$ & & \\
\hline VIX & $\begin{array}{l}0.006 \\
(0.24)\end{array}$ & $\begin{array}{l}-0.008 \\
(-1.03)\end{array}$ & & \\
\hline AAA-T3 & $\begin{array}{c}0.483^{* *} \\
(2.27)\end{array}$ & $\begin{array}{l}0.072 \\
(0.69)\end{array}$ & & \\
\hline T5KO-T5US & $\begin{array}{l}-0.269 \\
(-1.62)\end{array}$ & $\begin{array}{l}0.044 \\
(0.49)\end{array}$ & & \\
\hline FXRATE & $\begin{array}{c}-0.473^{*} \\
(-1.91)\end{array}$ & $\begin{array}{l}-0.013 \\
(-0.17)\end{array}$ & & \\
\hline BASERATE & $\begin{array}{l}-0.233 \\
(-0.85)\end{array}$ & $\begin{array}{c}0.329^{* * *} \\
(2.97)\end{array}$ & & \\
\hline Observations & 3,095 & 3,095 & 3,095 & 3,095 \\
\hline Number of bond & 82 & 82 & 82 & 82 \\
\hline Year\&Bond FE & YES & YES & YES & YES \\
\hline Adj.R-squared & 0.23 & 0.47 & 0.23 & 0.46 \\
\hline
\end{tabular}

Note: 1) All variables are described in the Appendix.

2) All t-statistics are based on robust standard errors clustered at the bond level in parentheses.

$3)^{*}, * *$ and $* * *$ represent significance at the $10 \%, 5 \%$ and $1 \%$ level, respectively.

We find that after controlling for other types of investors, the results for foreigners and insurance companies/pension funds are consistent with the earlier results (columns (1) through (4)), indicating that foreign investors and insurance companies/pension funds appear to reduce liquidity. However, after controlling for other types of investors, the 
coefficient on BANK become insignificant in the price impact regressions (columns (1) and (3)) while those are negative and significant in the market share regressions (columns (2) and (4)), which implies mixed results on the relationship between bank bond holdings and liquidity.

We also confirm that the results and adjusted R-square are similar between the fixed effect model with macroeconomic variables and year dummies (columns (1) and (2)) and the fixed effect model with monthly dummies (columns (3) and (4)). For further analyses, we choose the fixed effect models with macroeconomic variables and year dummies as our main panel regression model.

\section{Robustness Checks}

\subsection{Subsample Analyses: Types of Bonds}

Figures 1 and 2 show how liquidity measures and bond holdings by heterogeneous investors vary according to time and bond type. De Jong and Driessen (2005) show that bonds with lower ratings and longer maturities command a higher illiquidity premium, indicating that shorter maturity bonds are more liquid than longer maturity bonds. To further explore how various issued bond maturities affect the relationship between bond holdings by heterogenous investors and liquidity, we divide our sample into three groups, 3- , 5-, and 10-year KTBs, and carry out the regression model (2) using data on each bond type separately.

Table 4 shows the results of the effects of heterogeneous bond holdings on the price impact of trades, measured by LOG(AMI), and the market share, measured by LOG(MS). Columns (1) and (2) show the results for 3-year KTBs, Columns (3) and (4) the results for 5-year KTBs and Columns (5) and (6) the results for 10-year KTBs. 
Table 4. The Impact of Different Types of Investors on KTB Liquidity

\begin{tabular}{|c|c|c|c|c|c|c|}
\hline VARIABLES & $\begin{array}{c}\text { 3-YEA } \\
(1) \\
\text { LOG(AMI) }\end{array}$ & $\begin{array}{l}\text { KTB } \\
(2) \\
\text { LOG(MS) }\end{array}$ & $\begin{array}{c}5-Y E \\
(3) \\
\text { LOG(AMI) }\end{array}$ & $\begin{array}{l}\text { KTB } \\
(4) \\
\text { LOG(MS) }\end{array}$ & $\begin{array}{c}\text { 10-YE } \\
(5) \\
\text { LOG(AMI) }\end{array}$ & $\begin{array}{c}\text { KTB } \\
(6) \\
\text { LOG(MS) }\end{array}$ \\
\hline FOREIGNER & $\begin{array}{c}0.035^{* * *} \\
(3.22)\end{array}$ & $\begin{array}{c}-0.026^{* * *} \\
(-5.17)\end{array}$ & $\begin{array}{c}0.048^{*} \\
(1.92)\end{array}$ & $\begin{array}{c}-0.024^{*} \\
(-1.81)\end{array}$ & $\begin{array}{l}0.026 \\
(0.75)\end{array}$ & $\begin{array}{l}-0.000 \\
(-0.02)\end{array}$ \\
\hline INS\&PEN & $\begin{array}{l}-0.053 \\
(-1.71)\end{array}$ & $\begin{array}{l}0.017 \\
(1.14)\end{array}$ & $\begin{array}{c}0.089^{* * *} \\
(5.59)\end{array}$ & $\begin{array}{c}-0.036^{* * *} \\
(-3.27)\end{array}$ & $\begin{array}{l}-0.003 \\
(-0.12)\end{array}$ & $\begin{array}{l}0.004 \\
(0.35)\end{array}$ \\
\hline $\mathrm{FI}$ & $\begin{array}{c}-0.039^{*} \\
(-2.04)\end{array}$ & $\begin{array}{c}0.020^{* *} \\
(2.43)\end{array}$ & $\begin{array}{c}-0.065^{* * *} \\
(-3.39)\end{array}$ & $\begin{array}{c}0.063^{* * *} \\
(3.93)\end{array}$ & $\begin{array}{c}-0.271^{* * *} \\
(-5.66)\end{array}$ & $\begin{array}{c}0.158^{* * *} \\
(5.97)\end{array}$ \\
\hline BANK & $\begin{array}{c}-0.022^{*} \\
(-1.85)\end{array}$ & $\begin{array}{c}0.016^{* *} \\
(2.55)\end{array}$ & $\begin{array}{c}0.038^{* * *} \\
(2.84)\end{array}$ & $\begin{array}{l}-0.006 \\
(-0.55)\end{array}$ & $\begin{array}{c}-0.122^{* * *} \\
(-5.30)\end{array}$ & $\begin{array}{c}0.052^{* * *} \\
(3.77)\end{array}$ \\
\hline AGE & $\begin{array}{l}0.025 \\
(0.93)\end{array}$ & $\begin{array}{c}-0.030^{* *} \\
(-2.13)\end{array}$ & $\begin{array}{l}0.012 \\
(0.64)\end{array}$ & $\begin{array}{c}-0.028^{* *} \\
(-2.58)\end{array}$ & $\begin{array}{l}0.021 \\
(0.94)\end{array}$ & $\begin{array}{l}-0.013 \\
(-1.57)\end{array}$ \\
\hline BONDRET & $\begin{array}{c}-0.317^{* * *} \\
(-3.14)\end{array}$ & $\begin{array}{l}0.017 \\
(1.02)\end{array}$ & $\begin{array}{c}-0.275^{* * *} \\
(-6.39)\end{array}$ & $\begin{array}{l}-0.013 \\
(-0.78)\end{array}$ & $\begin{array}{c}-0.255^{* * *} \\
(-5.53)\end{array}$ & $\begin{array}{c}0.047^{* *} \\
(2.63)\end{array}$ \\
\hline LOG(OUTSHR) & $\begin{array}{l}-0.264 \\
(-0.67)\end{array}$ & $\begin{array}{l}0.214 \\
(1.08)\end{array}$ & $\begin{array}{c}-1.022^{* *} \\
(-2.69)\end{array}$ & $\begin{array}{l}0.266 \\
(1.38)\end{array}$ & $\begin{array}{l}0.507 \\
(0.77)\end{array}$ & $\begin{array}{l}-0.417 \\
(-1.05)\end{array}$ \\
\hline CEDIT RISK & $\begin{array}{c}-0.761^{*} \\
(-1.98)\end{array}$ & $\begin{array}{l}-0.430 \\
(-1.50)\end{array}$ & $\begin{array}{l}-0.469 \\
(-1.49)\end{array}$ & $\begin{array}{l}0.160 \\
(1.04)\end{array}$ & $\begin{array}{l}-0.102 \\
(-0.23)\end{array}$ & $\begin{array}{l}0.176 \\
(0.93)\end{array}$ \\
\hline LEVEL & $\begin{array}{c}-5.474^{*} \\
(-1.90)\end{array}$ & $\begin{array}{l}0.555 \\
(0.52)\end{array}$ & $\begin{array}{l}-0.916 \\
(-0.80)\end{array}$ & $\begin{array}{l}0.253 \\
(0.36)\end{array}$ & $\begin{array}{c}-3.634^{*} \\
(-1.88)\end{array}$ & $\begin{array}{l}0.337 \\
(0.48)\end{array}$ \\
\hline SLOPE & $\begin{array}{l}-1.207 \\
(-1.40)\end{array}$ & $\begin{array}{c}0.942^{* *} \\
(2.30)\end{array}$ & $\begin{array}{l}0.464 \\
(0.44)\end{array}$ & $\begin{array}{l}0.083 \\
(0.13)\end{array}$ & $\begin{array}{l}3.369^{*} \\
(1.91)\end{array}$ & $\begin{array}{l}0.594 \\
(0.88)\end{array}$ \\
\hline CURVATURE & $\begin{array}{l}5.431^{*} \\
(1.87)\end{array}$ & $\begin{array}{l}-0.249 \\
(-0.22)\end{array}$ & $\begin{array}{l}0.791 \\
(0.76)\end{array}$ & $\begin{array}{l}-0.323 \\
(-0.55)\end{array}$ & $\begin{array}{c}3.164^{*} \\
(1.80)\end{array}$ & $\begin{array}{l}-0.282 \\
(-0.40)\end{array}$ \\
\hline STKRET & $\begin{array}{l}0.107 \\
(0.33)\end{array}$ & $\begin{array}{l}-0.031 \\
(-0.25)\end{array}$ & $\begin{array}{l}-0.265 \\
(-1.10)\end{array}$ & $\begin{array}{l}-0.058 \\
(-0.69)\end{array}$ & $\begin{array}{l}-0.246 \\
(-0.89)\end{array}$ & $\begin{array}{l}-0.083 \\
(-0.63)\end{array}$ \\
\hline VIX & $\begin{array}{l}-0.039 \\
(-0.75)\end{array}$ & $\begin{array}{l}-0.012 \\
(-1.13)\end{array}$ & $\begin{array}{l}0.015 \\
(0.61)\end{array}$ & $\begin{array}{l}-0.005 \\
(-0.40)\end{array}$ & $\begin{array}{l}0.034 \\
(0.70)\end{array}$ & $\begin{array}{l}-0.014 \\
(-1.09)\end{array}$ \\
\hline AAA-T3 & $\begin{array}{l}0.072 \\
(0.09)\end{array}$ & $\begin{array}{l}-0.151 \\
(-0.54)\end{array}$ & $\begin{array}{c}0.621^{* *} \\
(2.07)\end{array}$ & $\begin{array}{l}0.068 \\
(0.61)\end{array}$ & $\begin{array}{l}0.479 \\
(1.26)\end{array}$ & $\begin{array}{l}0.002 \\
(0.01)\end{array}$ \\
\hline T5KO-T5US & $\begin{array}{l}-0.026 \\
(-0.06)\end{array}$ & $\begin{array}{l}0.082 \\
(0.94)\end{array}$ & $\begin{array}{l}-0.302 \\
(-1.44)\end{array}$ & $\begin{array}{l}0.106 \\
(0.81)\end{array}$ & $\begin{array}{l}-0.312 \\
(-1.17)\end{array}$ & $\begin{array}{l}-0.136 \\
(-1.03)\end{array}$ \\
\hline FXRATE & $\begin{array}{l}-0.030 \\
(-0.07)\end{array}$ & $\begin{array}{l}-0.013 \\
(-0.09)\end{array}$ & $\begin{array}{l}-0.242 \\
(-0.61)\end{array}$ & $\begin{array}{l}0.121 \\
(1.18)\end{array}$ & $\begin{array}{c}-0.933^{* *} \\
(-2.29)\end{array}$ & $\begin{array}{l}-0.091 \\
(-0.61)\end{array}$ \\
\hline BASERATE & $\begin{array}{l}-0.284 \\
(-0.45)\end{array}$ & $\begin{array}{l}-0.221 \\
(-1.04)\end{array}$ & $\begin{array}{l}0.105 \\
(0.29)\end{array}$ & $\begin{array}{l}0.291 \\
(1.48)\end{array}$ & $\begin{array}{l}0.380 \\
(0.98)\end{array}$ & $\begin{array}{l}0.381^{*} \\
(2.05)\end{array}$ \\
\hline Observations & 698 & 698 & 1,226 & 1,226 & 1,171 & 1,171 \\
\hline Number of bond & 25 & 25 & 32 & 32 & 25 & 25 \\
\hline Adj.R-squared & 0.31 & 0.75 & 0.33 & 0.61 & 0.29 & 0.39 \\
\hline
\end{tabular}

Note: 1) All variables are described in the Appendix.

2) All t-statistics are based on robust standard errors clustered at the bond level in parentheses.

$3)^{*}, * *$ and $* * *$ represent significance at the $10 \%, 5 \%$ and $1 \%$ level, respectively.

The results shows that the coefficients on FOREIGNER in the price impact regressions are positive and significant for the 3- and 5-year KTBs (columns (1) and (3)) and those in the market share regressions are negative and significant (columns (2) and (4)). The effects of foreign 
investors on 3- and 5-year bond liquidity are qualitatively similar to earlier results in Table 3, indicating a strong negative relationship between foreign ownership and Treasury bond liquidity. The effects, however, are insignificant for 10-year KTBs. Since foreign investors prefer to invest in 3- and 5- year KTBs (Panel B of Table 2 and Figure 2), the liquidity reducing effects by foreign investors are strong for bonds with relatively short maturity.

We also investigate the effects of financial investment companies on liquidity, and find that the results are qualitatively similar with the earlier empirical results in Table 3. The coefficients on FI in the price impact regressions are all negative and significant while those in the market share regressions are all positive and significant.

Furthermore, we find that the effect of bond holdings by insurance companies/pension funds and banks on liquidity varies with issuance maturities. The results show that the coefficient on INS\&PEN in the price impact regressions is positive and significant only for 5-year KTBs and that of the market share regressions is negative and significant only for 5-year KTBs, indicating the possibility that insurance companies/pension funds appeared to be informed trading and thereby reducing liquidity only for 5-year KTBs (columns (3) and (4)), but those are not significant for 3- and 10- year KTBs. On the other hand, the coefficients on BANK in the price impact regressions are negative and significant for 3- and 10-year KTBs while positive and significant for 5-year KTB bonds; The coefficients on BANK in the market share regressions are positive and significant for 3- and 10-year KTBs, indicating that bond holdings by banks appear to enhance liquidity for 3- and 10-year KTBs while reduce liquidity for 5-year KTBs.

\subsection{Sub-periods Analyses: Crisis vs. Post-crisis}

Figure 2 shows that bond holdings by foreign investors and financial investment companies, relative to other investors, temporarily fell around the 2008 global financial crisis and have increased afterward. In the wake of the GFC, government bond markets in emerging economies have rapidly developed due to the influence of abundant global liquidity and the flight-to-quality phenomenon. 


\section{BOK Working Paper No. 2018-3}

Table 5. Regression Results for the Sub-periods

Panel A. All Bonds

\begin{tabular}{|c|c|c|c|c|}
\hline \multirow{3}{*}{ VARIABLES } & \multicolumn{2}{|c|}{$\begin{array}{l}\text { Result for the 2007-2009 period } \\
\text { (Crisis) }\end{array}$} & \multicolumn{2}{|c|}{$\begin{array}{l}\text { Result for the 2010-2016 period } \\
\text { (Post-crisis) }\end{array}$} \\
\hline & $(1)$ & (2) & (3) & (4) \\
\hline & LOG(AMI) & LOG(MS) & LOG(AMI) & LOG(MS) \\
\hline \multirow[t]{2}{*}{ FOREIGNER } & 0.023 & -0.015 & $0.043^{* *}$ & $-0.029 * * *$ \\
\hline & $(1.50)$ & $(-1.35)$ & $(2.55)$ & $(-3.72)$ \\
\hline \multirow[t]{2}{*}{ INS\&PEN } & $0.060^{* * *}$ & $-0.050^{* * *}$ & 0.041 & -0.011 \\
\hline & (3.01) & $(-3.58)$ & $(1.66)$ & $(-0.93)$ \\
\hline \multirow[t]{2}{*}{$\mathrm{FI}$} & $-0.059^{* * *}$ & $0.045^{* * *}$ & $-0.098^{* * *}$ & $0.066^{* * *}$ \\
\hline & $(-3.75)$ & $(4.01)$ & $(-3.10)$ & $(4.01)$ \\
\hline \multirow[t]{2}{*}{ BANK } & -0.009 & 0.008 & 0.002 & -0.001 \\
\hline & $(-0.54)$ & $(0.76)$ & $(0.10)$ & $(-0.16)$ \\
\hline \multirow[t]{2}{*}{ AGE } & -0.008 & $-0.032^{* *}$ & 0.040 & $-0.034^{* * *}$ \\
\hline & $(-0.32)$ & $(-2.22)$ & $(1.67)$ & $(-2.71)$ \\
\hline \multirow[t]{2}{*}{ BONDRET } & $-0.255^{* * *}$ & 0.025 & $-0.235^{* * *}$ & -0.002 \\
\hline & $(-6.50)$ & $(1.34)$ & $(-5.95)$ & $(-0.15)$ \\
\hline \multirow[t]{2}{*}{ LOG(OUTSHR) } & -0.371 & 0.276 & -0.364 & 0.050 \\
\hline & $(-0.90)$ & $(0.91)$ & $(-0.79)$ & $(0.22)$ \\
\hline \multirow[t]{2}{*}{ CEDIT RISK } & -0.229 & 0.045 & 0.601 & -0.353 \\
\hline & $(-0.86)$ & $(0.23)$ & $(0.60)$ & $(-0.85)$ \\
\hline \multirow[t]{2}{*}{ LEVEL } & -0.631 & 0.584 & -0.372 & -0.269 \\
\hline & $(-0.86)$ & $(1.09)$ & $(-0.29)$ & $(-0.46)$ \\
\hline \multirow[t]{2}{*}{ SLOPE } & -0.114 & -0.161 & -0.324 & $0.978^{*}$ \\
\hline & $(-0.20)$ & $(-0.42)$ & $(-0.27)$ & $(1.67)$ \\
\hline \multirow[t]{2}{*}{ CURVATURE } & 0.510 & -0.386 & -0.034 & 0.217 \\
\hline & $(0.72)$ & $(-0.77)$ & $(-0.03)$ & $(0.40)$ \\
\hline \multirow[t]{2}{*}{ STKRET } & -0.176 & -0.078 & -0.336 & 0.093 \\
\hline & $(-0.80)$ & $(-0.91)$ & $(-1.25)$ & $(0.88)$ \\
\hline \multirow[t]{2}{*}{ VIX } & 0.023 & -0.019 & -0.009 & 0.004 \\
\hline & $(0.52)$ & $(-1.20)$ & $(-0.32)$ & $(0.50)$ \\
\hline \multirow[t]{2}{*}{ AAA-T3 } & $0.712^{* * *}$ & 0.099 & $2.039^{* * *}$ & 0.070 \\
\hline & $(3.12)$ & $(0.82)$ & $(2.68)$ & $(0.17)$ \\
\hline \multirow[t]{2}{*}{ T5KO-T5US } & -0.017 & 0.000 & -0.304 & -0.186 \\
\hline & $(-0.09)$ & $(0.00)$ & $(-0.95)$ & $(-1.40)$ \\
\hline \multirow[t]{2}{*}{ FXRATE } & $-0.942^{* * *}$ & -0.054 & -0.125 & $0.209^{*}$ \\
\hline & $(-3.07)$ & $(-0.51)$ & $(-0.31)$ & (1.92) \\
\hline \multirow[t]{2}{*}{ BASERATE } & 0.472 & 0.140 & 0.464 & 0.175 \\
\hline & $(1.43)$ & $(0.83)$ & $(0.92)$ & $(0.74)$ \\
\hline Observations & 1,146 & 1,146 & 1,949 & 1,949 \\
\hline Number of bond & 49 & 49 & 62 & 62 \\
\hline Adj.R-squared & 0.16 & 0.45 & 0.24 & 0.43 \\
\hline
\end{tabular}


Panel B. Different Types of Bonds

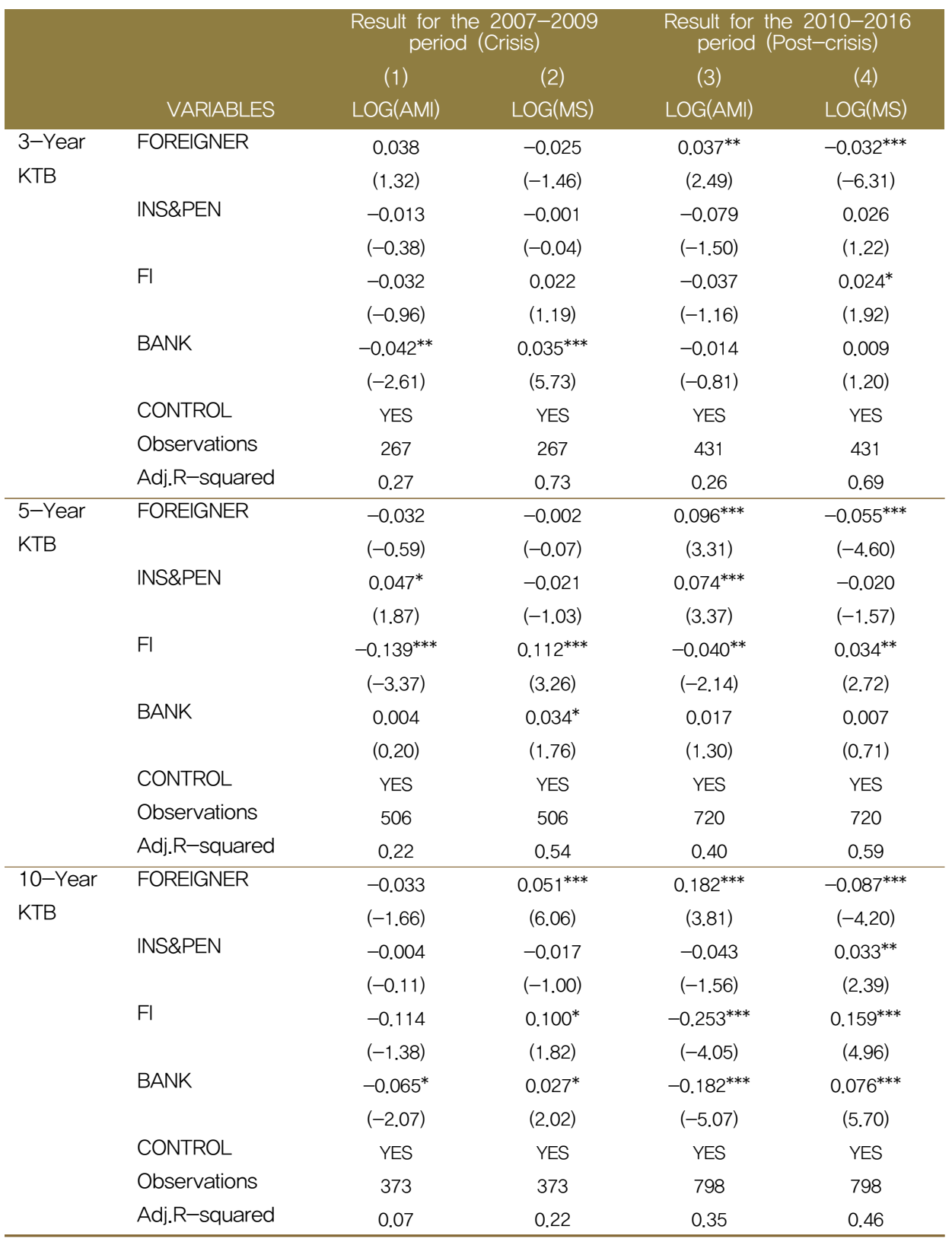

Note: 1) All variables are described in the Appendix.

2) All t-statistics are based on robust standard errors clustered at the bond level in parentheses.

$3)^{*}, * *$ and $* * *$ represent significance at the $10 \%, 5 \%$ and $1 \%$ level, respectively.

4) CONTROL indicates that bond characteristic and macroeconomic variables are controlled in the regression. 
To determine whether the effect of foreign bond holding on liquidity differs between the 2007-2009 (crisis) period and the 2010-2016 (post-crisis) period, we estimate regression models (2) using data on each sub-period separately. Panel A of Table 5 shows the results for all bonds. We find that foreign investors have a significantly negative impact on liquidity in the post-crisis period.

This is consistent with the earlier results that foreign investors have negative impacts on liquidity because the increases in bond holdings in the post-crisis period lead to significantly lower liquidity. On the other hand, we find that insurance companies/pension funds appear to reduce liquidity in the pre-crisis period rather than the post-crisis period by increasing the price impact of trades and reducing the market share (Columns (1) and (2) in Panel A). We further find that financial investment companies seem to participate in market making more actively in the post-crisis period than the crisis-period, showing more significant and greater values in the post-crisis period. This result may be caused by the low interest rates in advanced countries associated with quantitative easing in the post-crisis period.

Panel B reports the results for 3-, 5-, and 10- year KTBs. Consistent with Panel A of Table 5, the coefficients on FOREIGNER in the post-crisis period are all positive and significant in the price impact of trade regressions for 3-, 5- and 10-year KTBs, whereas they are negative and significant in the market share regressions. Similar to earlier results, the growing ownership by foreign investors appears to worsen liquidity in those bonds.

In addition, we find that the coefficients on INS\&PEN are positive and significant for 5-year KTBs in the price impact regressions in both sub-periods, but those are not significant for 3- and 10-year KTB bonds.

On the other hand, the coefficients on FI are negative and significant in the price impact regressions for 3-, 5-, and 10-year KTBs in the post-crisis period while being positive in the market share regressions. The coefficients on BANK for 3- and 10-year KTBs in the crisis period are negative and significant in the price impact regressions while being positive and significant 
in the market share. With respect to 10- year KTBs, the coefficients on BANK in the post-crisis period are more significant than those in the crisis period.

Overall, liquidity providing activities by banks and financial investment companies are stronger for 10-year KTBs in the post-crisis period, during which the rule on PDs' market making or spread reducing activities in the exchange was reformed (October 2010). The reformed rule therefore may indirectly contribute to liquidity improvement in the OTC market because PDs are likely to offer their quotes at similar values in both the OTC market and the exchange.13)

\subsection{Subsample Analyses: On-the-runs vs. Off-the-runs}

The mostly recently issued on-the-run bonds are extremely liquid and generally trade at the higher prices than the more seasoned, off-the-run, bonds (e.g., Fleming, 2003; Goldreich, Hanke, and Nath, 2005; Pasquariello and Vega, 2009). As shown in Figure 3, heterogeneous investors tend to hold different portfolio compositions between on-the-runs and off-the-runs, but this poses a question about how heterogeneous investors affect on/off-the-run liquidity.

To shed additional light on the effect of heterogeneous bond holdings on on/off-the-run liquidity, we add a dummy variable for on-the-runs ( $\mathrm{ON})$ and four interaction terms between on-the-runs and bond holding by four types of investors (ON*FOREIGNER, ON*INS\&PEN, ON*AM, and ON*BANK) to regression equation (2) and show the results in Panels $\mathrm{A}$ and $\mathrm{B}$ of Table 6. $\mathrm{ON}$ is the dummy variable that takes value one if the status of the bond is on-the-run.

13) For robustness, we divide our sample into pre- and post-reform periods and conduct the same regression analyses as before. We find that the results are qualitatively similar to those in Table 5. 
Table 6. Regression Results for On-the-runs and Off-the-runs

Panel A. All Bonds: Interaction between On-the runs and Heterogeneous Investor Ownership

\begin{tabular}{|c|c|c|c|c|}
\hline VARIABLES & $\begin{array}{c}(1) \\
\text { LOG(AMI) }\end{array}$ & $\begin{array}{c}(2) \\
\text { LOG(MS) }\end{array}$ & $\begin{array}{c}\text { (3) } \\
\text { LOG(AMI) }\end{array}$ & $\begin{array}{c}(4) \\
\text { LOG(MS) }\end{array}$ \\
\hline FOREIGNER & $\begin{array}{c}0.039^{* * *} \\
(3.66)\end{array}$ & $\begin{array}{c}-0.021^{* * *} \\
(-3.31)\end{array}$ & $\begin{array}{c}0.044^{* * *} \\
(4.30)\end{array}$ & $\begin{array}{c}-0.022^{* * *} \\
(-3.35)\end{array}$ \\
\hline INS\&PEN & $\begin{array}{c}0.058^{* * *} \\
(3.43)\end{array}$ & $\begin{array}{c}-0.032^{* * *} \\
(-3.68)\end{array}$ & $\begin{array}{c}0.063^{* * *} \\
(3.61)\end{array}$ & $\begin{array}{c}-0.034^{* * *} \\
(-3.69)\end{array}$ \\
\hline $\mathrm{FI}$ & $\begin{array}{c}-0.062^{* * *} \\
(-3.86)\end{array}$ & $\begin{array}{c}0.047^{* * *} \\
(4.63)\end{array}$ & $\begin{array}{c}-0.063^{* * *} \\
(-3.75)\end{array}$ & $\begin{array}{c}0.049^{* * *} \\
(4.58)\end{array}$ \\
\hline BANK & $\begin{array}{l}0.010 \\
(0.82)\end{array}$ & $\begin{array}{l}-0.007 \\
(-1.26)\end{array}$ & $\begin{array}{l}0.018 \\
(1.48)\end{array}$ & $\begin{array}{c}-0.012^{* *} \\
(-2.08)\end{array}$ \\
\hline 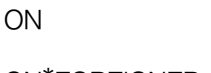 & $\begin{array}{c}-0.695^{* *} \\
(-2.16)\end{array}$ & $\begin{array}{c}0.863^{* * *} \\
(4.10)\end{array}$ & $\begin{array}{l}-0.741 \\
(-1.09)\end{array}$ & $\begin{array}{c}1.134^{* * *} \\
(2.70)\end{array}$ \\
\hline ON*FOREIGNER & $\begin{array}{c}-0.038^{* *} \\
(-2.49)\end{array}$ & $\begin{array}{c}0.021^{* *} \\
(2.10)\end{array}$ & $\begin{array}{c}-0.032^{* *} \\
(-2.03)\end{array}$ & $\begin{array}{c}0.016^{*} \\
(1.68)\end{array}$ \\
\hline ON*INS\&PEN & & & $\begin{array}{c}-0.033^{* * *} \\
(-2.92)\end{array}$ & $\begin{array}{c}0.016^{* *} \\
(2.40)\end{array}$ \\
\hline ON*AM & & & $\begin{array}{c}0.059^{* *} \\
(2.59)\end{array}$ & $\begin{array}{c}-0.043^{* * *} \\
(-3.64)\end{array}$ \\
\hline ON*BANK & & & $\begin{array}{l}-0.008 \\
(-0.47)\end{array}$ & $\begin{array}{c}0.015^{* *} \\
(2.01)\end{array}$ \\
\hline CONTROL & YES & YES & YES & YES \\
\hline Observations & 3,095 & 3,095 & 3,095 & 3,095 \\
\hline Adj.R-squared & 0.24 & 0.51 & 0.25 & 0.52 \\
\hline
\end{tabular}

Panel B. Different Types of Bonds: Interaction between On-the runs and Heterogeneous Investor Ownership

\begin{tabular}{|c|c|c|c|c|c|c|}
\hline \multirow[b]{2}{*}{ VARIABLES } & \multicolumn{2}{|c|}{ 3-YEAR KTB } & \multicolumn{2}{|c|}{ 5-YEAR KTB } & \multicolumn{2}{|c|}{ 10-YEAR KTB } \\
\hline & $\begin{array}{c}(1) \\
\text { LOG(AMI) }\end{array}$ & $\begin{array}{c}(2) \\
\text { LOG(MS) }\end{array}$ & $\begin{array}{c}(3) \\
\text { LOG(AMI) }\end{array}$ & $\begin{array}{c}(4) \\
\mathrm{LOG}(\mathrm{MS})\end{array}$ & $\begin{array}{c}(5) \\
\text { LOG(AMI) }\end{array}$ & $\begin{array}{c}(6) \\
\text { LOG(MS) }\end{array}$ \\
\hline FOREIGNER & $\begin{array}{c}0.041^{* * *} \\
(3.65)\end{array}$ & $\begin{array}{c}-0.025^{* * *} \\
(-4.47)\end{array}$ & $\begin{array}{l}0.035 \\
(1.37)\end{array}$ & $\begin{array}{l}-0.007 \\
(-0.49)\end{array}$ & $\begin{array}{c}0.114^{* * *} \\
(3.31)\end{array}$ & $\begin{array}{c}-0.058^{* *} \\
(-2.68)\end{array}$ \\
\hline INS\&PEN & $\begin{array}{l}-0.056 \\
(-1.49)\end{array}$ & $\begin{array}{l}0.017 \\
(1.04)\end{array}$ & $\begin{array}{c}0.086^{* * *} \\
(5.26)\end{array}$ & $\begin{array}{c}-0.029^{* * *} \\
(-2.81)\end{array}$ & $\begin{array}{l}-0.037 \\
(-1.47)\end{array}$ & $\begin{array}{l}0.018 \\
(1.48)\end{array}$ \\
\hline $\mathrm{FI}$ & $\begin{array}{c}-0.044^{*} \\
(-1.96)\end{array}$ & $\begin{array}{c}0.024^{* *} \\
(2.75)\end{array}$ & $\begin{array}{c}-0.071^{* * *} \\
(-3.31)\end{array}$ & $\begin{array}{c}0.075^{* * *} \\
(4.27)\end{array}$ & $\begin{array}{c}-0.292^{* * *} \\
(-6.30)\end{array}$ & $\begin{array}{c}0.152^{* * *} \\
(6.15)\end{array}$ \\
\hline BANK & $\begin{array}{c}-0.031^{* * *} \\
(-2.82)\end{array}$ & $\begin{array}{c}0.018^{* *} \\
(2.80)\end{array}$ & $\begin{array}{c}0.038^{* *} \\
(2.67)\end{array}$ & $\begin{array}{l}-0.002 \\
(-0.18)\end{array}$ & $\begin{array}{c}-0.162^{* * *} \\
(-4.30)\end{array}$ & $\begin{array}{c}0.062^{* * *} \\
(4.28)\end{array}$ \\
\hline ON & $\begin{array}{c}-2.073^{*} \\
(-1.78)\end{array}$ & $\begin{array}{l}0.465 \\
(1.28)\end{array}$ & $\begin{array}{l}-1.179 \\
(-0.68)\end{array}$ & $\begin{array}{c}2.090^{* *} \\
(2.64)\end{array}$ & $\begin{array}{c}-2.942^{*} \\
(-2.04)\end{array}$ & $\begin{array}{c}1.870^{* *} \\
(2.42)\end{array}$ \\
\hline ON*FOREIGNER & $\begin{array}{c}-0.061^{* * *} \\
(-3.33)\end{array}$ & $\begin{array}{c}0.026^{* * *} \\
(3.14)\end{array}$ & $\begin{array}{l}0.018 \\
(0.49)\end{array}$ & $\begin{array}{l}-0.017 \\
(-0.94)\end{array}$ & $\begin{array}{c}-0.072^{*} \\
(-2.03)\end{array}$ & $\begin{array}{c}0.060^{* * *} \\
(3.08)\end{array}$ \\
\hline ON*INS\&PEN & $\begin{array}{l}0.045 \\
(0.96)\end{array}$ & $\begin{array}{l}-0.017 \\
(-0.89)\end{array}$ & $\begin{array}{l}-0.011 \\
(-0.30)\end{array}$ & $\begin{array}{l}0.008 \\
(0.52)\end{array}$ & $\begin{array}{l}0.003 \\
(0.10)\end{array}$ & $\begin{array}{l}-0.001 \\
(-0.06)\end{array}$ \\
\hline ON*AM & $\begin{array}{c}0.071^{* *} \\
(2.29)\end{array}$ & $\begin{array}{c}-0.022^{*} \\
(-1.95)\end{array}$ & $\begin{array}{l}0.023 \\
(0.47)\end{array}$ & $\begin{array}{c}-0.063^{* *} \\
(-2.58)\end{array}$ & $\begin{array}{c}0.296^{* * *} \\
(4.76)\end{array}$ & $\begin{array}{c}-0.154^{* * *} \\
(-4.65)\end{array}$ \\
\hline ON*BANK & $\begin{array}{l}0.043 \\
(1.00)\end{array}$ & $\begin{array}{l}0.008 \\
(0.64)\end{array}$ & $\begin{array}{c}-0.037^{*} \\
(-1.90)\end{array}$ & $\begin{array}{l}0.013 \\
(1.18)\end{array}$ & $\begin{array}{c}0.119^{* * *} \\
(3.06)\end{array}$ & $\begin{array}{c}-0.043^{* * *} \\
(-3.33)\end{array}$ \\
\hline CONTROL & YES & YES & YES & YES & YES & YES \\
\hline Observations & 698 & 698 & 1,226 & 1,226 & 1,171 & 1,171 \\
\hline Adj.R-squared & 0.32 & 0.76 & 0.34 & 0.63 & 0.33 & 0.46 \\
\hline
\end{tabular}


Panel C. Subsample: On-the-run vs. Off-the-run

\begin{tabular}{|c|c|c|c|c|}
\hline \multirow{3}{*}{ VARIABLES } & \multicolumn{2}{|c|}{ ON-THE-RUN BOND } & \multicolumn{2}{|c|}{ OFF-THE-RUN BOND } \\
\hline & (1) & (2) & (3) & (4) \\
\hline & LOG(AMI) & LOG(MS) & LOG(AMI) & LOG(MS) \\
\hline \multirow[t]{2}{*}{ FOREIGNER } & $0.034^{* *}$ & 0.004 & $0.062^{* * *}$ & $-0.027^{* * *}$ \\
\hline & $(2.27)$ & $(0.92)$ & (4.28) & $(-3.10)$ \\
\hline \multirow[t]{2}{*}{ INS\&PEN } & -0.001 & 0.001 & $0.071^{* * *}$ & $-0.033^{* * *}$ \\
\hline & $(-0.07)$ & $(0.24)$ & (3.50) & $(-3.15)$ \\
\hline \multirow[t]{2}{*}{$\mathrm{FI}$} & 0.022 & 0.002 & $-0.053^{* * *}$ & $0.048^{* * *}$ \\
\hline & (1.05) & $(0.18)$ & $(-2.83)$ & (3.85) \\
\hline \multirow[t]{2}{*}{ BANK } & $-0.032^{* *}$ & $0.006^{*}$ & 0.021 & -0.007 \\
\hline & $(-2.38)$ & $(1.88)$ & $(1.42)$ & $(-0.95)$ \\
\hline \multirow[t]{2}{*}{ AGE } & 0.024 & -0.058 & 0.018 & -0.010 \\
\hline & $(0.27)$ & $(-1.63)$ & $(1.44)$ & $(-1.49)$ \\
\hline \multirow[t]{2}{*}{ BONDRET } & -0.015 & $0.029^{* *}$ & $-0.265^{* * *}$ & 0.005 \\
\hline & $(-0.37)$ & $(2.29)$ & $(-8.53)$ & $(0.44)$ \\
\hline \multirow{2}{*}{ LOG(OUTSHR) } & -0.601 & $0.691^{* * *}$ & -1.124 & $1.212^{* * *}$ \\
\hline & $(-1.40)$ & $(4.24)$ & $(-1.24)$ & $(2.70)$ \\
\hline \multirow[t]{2}{*}{ CEDIT RISK } & -0.612 & 0.035 & $-0.559^{* *}$ & 0.090 \\
\hline & $(-1.02)$ & $(0.24)$ & $(-2.08)$ & $(0.69)$ \\
\hline \multirow[t]{2}{*}{ LEVEL } & -0.448 & 0.300 & 0.701 & -0.728 \\
\hline & $(-0.46)$ & $(0.89)$ & $(1.02)$ & $(-1.35)$ \\
\hline \multirow[t]{2}{*}{ SLOPE } & 1.083 & -0.249 & $-1.159^{* *}$ & $1.049^{* *}$ \\
\hline & $(1.63)$ & $(-0.72)$ & $(-2.11)$ & $(2.41)$ \\
\hline \multirow[t]{2}{*}{ CURVATURE } & 1.115 & -0.459 & -0.701 & 0.681 \\
\hline & $(1.18)$ & $(-1.27)$ & $(-1.09)$ & $(1.33)$ \\
\hline \multirow[t]{2}{*}{ STKRET } & 0.376 & -0.018 & -0.153 & -0.078 \\
\hline & $(0.94)$ & $(-0.27)$ & $(-0.91)$ & $(-1.04)$ \\
\hline \multirow[t]{2}{*}{ VIX } & 0.060 & -0.006 & 0.001 & -0.008 \\
\hline & $(1.37)$ & $(-0.69)$ & $(0.03)$ & $(-0.90)$ \\
\hline \multirow[t]{2}{*}{ AAA-T3 } & 0.577 & -0.225 & 0.328 & 0.161 \\
\hline & $(1.66)$ & $(-1.64)$ & $(1.56)$ & $(1.66)$ \\
\hline \multirow[t]{2}{*}{ T5KO-T5US } & $-0.817^{* * *}$ & $0.227^{* *}$ & -0.152 & 0.029 \\
\hline & $(-3.31)$ & $(2.18)$ & $(-0.87)$ & $(0.31)$ \\
\hline \multirow[t]{2}{*}{ FXRATE } & -0.027 & 0.004 & -0.464 & -0.052 \\
\hline & $(-0.06)$ & $(0.03)$ & $(-1.65)$ & $(-0.61)$ \\
\hline \multirow[t]{2}{*}{ BASERATE } & 0.376 & -0.078 & -0.219 & $0.328^{* * *}$ \\
\hline & $(0.76)$ & $(-0.57)$ & $(-0.75)$ & $(3.06)$ \\
\hline Observations & 302 & 302 & 2,793 & 2,793 \\
\hline Number of bond & 54 & 54 & 81 & 81 \\
\hline Adj.R-squared & 0.21 & 0.69 & 0.21 & 0.39 \\
\hline
\end{tabular}

Note: 1) All variables are described in the Appendix.

2) All t-statistics are based on robust standard errors clustered at the bond level in parentheses.

$3)^{*}, * *$ and $* * *$ represent significance at the $10 \%, 5 \%$ and $1 \%$ level, respectively.

4) CONTROL indicates that bond characteristic and macroeconomic variables are controlled in the regression. 
Panel A reports the result for all bonds with those variables. Columns (1) and (3) show the results for the price impact regression, and columns (2) and (4) the results for the market share. Consistent with Figure 3, the coefficients on $\mathrm{ON}$ in the price impact regression are negative and significant, while those in the market share are positive and significant.

The coefficients on FOREIGNER and INS\&PEN are positive and significant in the price impact regression and negative and significant in the market share regression, indicating that bonds with higher foreign or insurance/pension ownership exhibit higher price impacts and lower market shares. The coefficients on ON*FOREIGNER and ON*INS\&PEN are negative and significant in the price impact but positive and significant in the market share regressions. The results indicate that liquidity-reducing effects of foreign investors and insurance companies/pension funds are smaller for on-the runs. ${ }^{14)}$

On the other hand, the coefficients on FI are negative and significant in the price impact regressions while being positive and significant in the market share regressions, indicating that bonds with higher ownership by financial investment companies exhibit lower price impacts and higher market shares. The coefficient on $\mathrm{ON}^{*} \mathrm{AM}$ is positive and significant in the price impact regression and negative and significant in the market share regressions, indicating a smaller liquidity-enhancing effect of financial investment companies in on-the-runs.

For 3-, 5- and 10-year KTBs, we carry out the same regression analyses with Panel A of Table 6 and document the results in Panel B. For 3- and 10-year KTBs, the coefficients on FOREIGNER are positive and significant in the price impact regression while being negative and significant in the market share regression. The coefficients on FOREIGNER*ON are negative and significant in the price impact regression while being positive and significant in the market share regression. The results indicate that the

14) For the robustness check, we estimate regression model (2) for the subsamples, on-the-runs and off-the-runs, respectively. Consistent with Panel A of Table 6, the liquidity-reducing effects of foreign investors and insurance companies/pension funds are stronger for off-the-runs. 
strong liquidity-reducing effect of foreign ownership becomes weaker for the 3- and 10-year on-the-runs.

For 5-year KTBs only, the coefficients on INS\&PEN are positive and significant in the price impact regression and negative and significant in the market share regression, but coefficients on INS\&PEN*ON are insignificant for all regression models. The liquidity-enhancing effects of financial investment companies are smaller for 3- and 10-year on-the-runs. (See columns (1), (2), (3) and (4)). For 3- and 10-year KTBs, the coefficients on BANK are negative and significant in the price impact regression, indicating liquidity enhancing effects of banks in 3- and 10-year bonds. For 10-year KTBs, the coefficients on $\mathrm{ON}^{*} \mathrm{BANK}$ are positive and significant in the price impact regression and negative in the market share regression, indicating a smaller liquidity enhancing effect of banks for 10-year on-the runs.

To determine whether the effect of heterogeneous ownership on the price impact of trades and market share differs between on-the-run and off-the-run bonds, we estimate the regression equation (2) for each subsample separately. In Panel $\mathrm{C}$ of Table 6, the left half of each panel presents the results for the on-the-run bond, and the right half presents the results for the off-the-run bond. Columns (1) and (3) show the results for the price impact of trades, and columns (2) and (4) show the results for the market share. Similar to the results in Panel A and Panel B, the price impact of trades increases with foreign ownership for both on-the-run and off-the-run bonds, while the market share decreases with foreign ownership only for the off-the-run bonds, indicating a greater effect of foreign ownership on the price impact of trades and market share in the off-the-bonds. The price impact of trades increases with bond holdings by insurance and pension companies, while the market share decreases with them only for the off-the-run bonds. These indicate either that off-the-run-bonds have greater asymmetry than on-the-run bonds or that the former are more undervalued than the latter.

On the other hand, the price impact of trades decreases with bond holdings by financial investment companies, and the market share increases 


\section{BOK Working Paper No. 2018-3}

Table 7. Regression Results for Using Alternative Panel Regression Models

\begin{tabular}{|c|c|c|c|c|}
\hline VARIABLES & $\begin{array}{c}\text { ONE } \\
(1) \\
\text { LOG(AMI) }\end{array}$ & $\begin{array}{l}\text { GMM } \\
\text { (2) } \\
\text { LOG(MS) }\end{array}$ & $\begin{array}{c}\text { (3) } \\
\text { LOG(AMI) }\end{array}$ & $\begin{array}{l}\text { LS } \\
\text { LOG(M) }\end{array}$ \\
\hline FOREIGNER & $\begin{array}{c}0.052^{* * *} \\
(3.56)\end{array}$ & $\begin{array}{c}-0.031^{* * *} \\
(-4.41)\end{array}$ & $\begin{array}{c}0.014^{* * *} \\
(4.26)\end{array}$ & $\begin{array}{c}-0.004^{* * *} \\
(-3.28)\end{array}$ \\
\hline INS\&PEN & $\begin{array}{l}0.028 \\
(1.00)\end{array}$ & $\begin{array}{l}-0.008 \\
(-0.77)\end{array}$ & $\begin{array}{c}0.019^{* * *} \\
(6.49)\end{array}$ & $\begin{array}{c}-0.003^{* * *} \\
(-2.75)\end{array}$ \\
\hline $\mathrm{Fl}$ & $\begin{array}{l}-0.019 \\
(-1.01)\end{array}$ & $\begin{array}{l}0.017^{*} \\
(1.79)\end{array}$ & $\begin{array}{c}-0.021^{* * *} \\
(-4.39)\end{array}$ & $\begin{array}{c}0.007^{* * *} \\
(3.43)\end{array}$ \\
\hline BANK & $\begin{array}{l}-0.008 \\
(-0.34)\end{array}$ & $\begin{array}{l}-0.003 \\
(-0.33)\end{array}$ & $\begin{array}{l}0.002 \\
(0.67)\end{array}$ & $\begin{array}{l}-0.001 \\
(-1.18)\end{array}$ \\
\hline AGE & $\begin{array}{l}0.021 \\
(1.25)\end{array}$ & $\begin{array}{c}-0.018^{* * *} \\
(-3.05)\end{array}$ & $\begin{array}{c}0.014^{* * *} \\
(8.12)\end{array}$ & $\begin{array}{c}-0.007^{* * *} \\
(-9.43)\end{array}$ \\
\hline BONDRET & $\begin{array}{c}-0.232^{* * *} \\
(-7.02)\end{array}$ & $\begin{array}{l}0.013 \\
(1.16)\end{array}$ & $\begin{array}{c}-0.216^{* * *} \\
(-6.24)\end{array}$ & $\begin{array}{l}0.009 \\
(0.73)\end{array}$ \\
\hline LOG(OUTSHR) & $\begin{array}{l}-0.339 \\
(-1.08)\end{array}$ & $\begin{array}{l}0.227^{*} \\
(1.71)\end{array}$ & $\begin{array}{c}0.156^{* *} \\
(2.37)\end{array}$ & $\begin{array}{l}-0.000 \\
(-0.02)\end{array}$ \\
\hline CEDIT RISK & $\begin{array}{l}-0.251 \\
(-1.03)\end{array}$ & $\begin{array}{l}-0.011 \\
(-0.08)\end{array}$ & $\begin{array}{c}-0.226^{* *} \\
(-2.41)\end{array}$ & $\begin{array}{l}-0.003 \\
(-0.08)\end{array}$ \\
\hline LEVEL & $\begin{array}{l}0.305 \\
(0.49)\end{array}$ & $\begin{array}{l}0.052 \\
(0.20)\end{array}$ & $\begin{array}{l}0.175 \\
(0.77)\end{array}$ & $\begin{array}{l}-0.135 \\
(-1.52)\end{array}$ \\
\hline SLOPE & $\begin{array}{l}-0.469 \\
(-0.93)\end{array}$ & $\begin{array}{l}0.298 \\
(1.30)\end{array}$ & $\begin{array}{l}-0.161 \\
(-0.73)\end{array}$ & $\begin{array}{l}0.160^{*} \\
(1.82)\end{array}$ \\
\hline CURVATURE & $\begin{array}{l}-0.573 \\
(-0.92)\end{array}$ & $\begin{array}{l}-0.007 \\
(-0.02)\end{array}$ & $\begin{array}{l}0.133 \\
(0.67)\end{array}$ & $\begin{array}{l}0.106 \\
(1.39)\end{array}$ \\
\hline STKRET & $\begin{array}{l}-0.182 \\
(-1.12)\end{array}$ & $\begin{array}{l}-0.049 \\
(-0.70)\end{array}$ & $\begin{array}{l}0.131 \\
(0.77)\end{array}$ & $\begin{array}{c}-0.143^{* *} \\
(-2.11)\end{array}$ \\
\hline VIX & $\begin{array}{l}0.014 \\
(0.55)\end{array}$ & $\begin{array}{l}-0.009 \\
(-1.25)\end{array}$ & $\begin{array}{l}0.035 \\
(1.19)\end{array}$ & $\begin{array}{l}-0.009 \\
(-0.94)\end{array}$ \\
\hline AAA-T3 & $\begin{array}{l}0.400 \\
(1.58)\end{array}$ & $\begin{array}{l}0.010 \\
(0.11)\end{array}$ & $\begin{array}{c}0.310^{* * *} \\
(3.24)\end{array}$ & $\begin{array}{l}-0.028 \\
(-0.76)\end{array}$ \\
\hline T5KO-T5US & $\begin{array}{l}-0.228 \\
(-1.14)\end{array}$ & $\begin{array}{l}0.014 \\
(0.23)\end{array}$ & $\begin{array}{c}-0.175^{* *} \\
(-2.30)\end{array}$ & $\begin{array}{l}-0.013 \\
(-0.48)\end{array}$ \\
\hline FXRATE & $\begin{array}{c}-0.482^{*} \\
(-1.95)\end{array}$ & $\begin{array}{l}0.052 \\
(0.69)\end{array}$ & $\begin{array}{l}-0.250 \\
(-1.14)\end{array}$ & $\begin{array}{l}0.009 \\
(0.11)\end{array}$ \\
\hline BASERATE & $\begin{array}{l}0.206 \\
(0.71)\end{array}$ & $\begin{array}{l}0.120 \\
(1.43)\end{array}$ & $\begin{array}{l}-0.187 \\
(-1.62)\end{array}$ & $\begin{array}{l}0.030 \\
(0.66)\end{array}$ \\
\hline LOG(AMI)t-1 & $\begin{array}{l}0.012 \\
(0.30)\end{array}$ & & $\begin{array}{c}0.522^{* * *} \\
(26.30)\end{array}$ & \\
\hline LOG(MS)t-1 & & $\begin{array}{c}0.316^{* * *} \\
(6.10)\end{array}$ & & $\begin{array}{c}0.755^{* * *} \\
(49.49)\end{array}$ \\
\hline Observations & 2,965 & 2,965 & 3,095 & 3,095 \\
\hline Number of bond & 81 & 81 & & \\
\hline Year \& Bond FE & YES & YES & YES & YES \\
\hline Newey west S.E & & & YES & YES \\
\hline P-value $A R(1)$ & 0.000 & 0.000 & & \\
\hline P-value AR(2) & 0.924 & 0.166 & & \\
\hline
\end{tabular}

Note: 1) All variables are described in the Appendix.

$2)^{*}, * *$ and $* * *$ represent significance at the $10 \%, 5 \%$ and $1 \%$ level, respectively. 
with them only in off-the-run bonds. The price impact of trades decreases with bank holdings and the market share decreases with them only in on-the-run bonds, suggesting that financial investment companies provide liquidity for off-the-run bonds while banks improve liquidity for on-the-run bonds.

\subsection{Alternative Panel Regression Model}

To further examine the cross-sectional importance of bond holdings by heterogeneous investors for Treasury bond illiquidity, we carry out two alternative methods for the panel regression analyses: GMM, and pooled OLS with Newey-West adjusted standard errors, using the following regression equation.

$$
\begin{aligned}
L I Q_{i t} & =a L I Q_{i t-1}+\beta_{1} \text { FOREIGNER }_{i t-1}+\beta_{2} \text { INS\& }_{\text {PEN }} \text { it }-1_{1}+\beta_{3} F_{i t-1}+\beta_{4} \text { BANK }_{i t-1} \\
& =\sum_{j} \delta_{j} \text { Bond control }_{i, t}+\sum_{j} \gamma_{j} \text { Macrocontrol }_{t}+\epsilon_{i t}
\end{aligned}
$$

We first estimate regression model (3) using the traditional first-differenced GMM or one-step GMM estimator (Arellano and Bond, 1991)15). For the one-step GMM estimation, we include lagged levels of the dependent variable as instruments for their first differences, which eliminate the bond fixed effects.16)

Table 7 shows the results for the traditional first-differenced GMM estimator (Arellano and Bond, 1991) with clustered standard errors at the bond level and for the pooled OLS with Newey-West adjusted standard errors that are estimated from 3,095 bond-month observations. The left half of panel shows the results for the GMM and the right half shows the results for

15) The GMM model has the advantage of correcting to some degree for the biases introduced by endogeneity problems.

16) For our main equation (2), we exclude the lagged dependent variables from the fixed effect model since Nickell's bias (1981) or dynamic panel bias shows that the estimators from the fixed effect model could be biased when a lagged dependent variable is included. 
the pooled OLS.

The results are qualitatively similar to those in Table 3. For both the GMM estimation and the pooled OLS, the coefficients on FOREIGNER are positive and significant in the price impact of trades while being negative and significant in the market share regressions.

The coefficients on FI are mostly negative and significant in the price impact regressions while being positive and significant in the market share regressions. ${ }^{17)}$ The results indicate that foreign investors reduce liquidity while financial investment companies improve liquidity. On the other hand, the coefficients on INS\&PEN are sensitive to the model specifications and those on BANK are insignificant. We therefore conclude that our main results are robust to alternative model specifications.

\section{Summary and Concluding Remarks}

There has been an ongoing debate as to how heterogenous investors affect the liquidity of domestic equity and bond market in emerging economies. In particular, both regulators and researchers have investigated the effects of various types of institutional investors on liquidity in the stock market. To our knowledge, however, none of the studies have examined the direct relationship between bond holdings and liquidity in the government bond market.

This paper therefore analyzes the effects of various types of institutional investors on Treasury bond liquidity in the OTC market with Korean bond-level panel data from January 2007 to December 2016. Using a fixed effect model, we find that bonds with higher ownership by foreign investors and domestic insurance companies/pension funds have greater price impacts of trades and lower market trading activities, all indicating lower liquidity. Variations of bond holdings by each investor type suggest the possibility that negative effects on liquidity are likely to be

17) Our GMM models pass the AR(2) since the null hypotheses for no-serial correlations are not rejected. 
associated with informed trading and infrequent trading by foreign investors. We also find that an increase in bonds holdings by financial investment companies contributes to improving liquidity.

After dividing the sample into three types of bonds-3-, 5-, and 10-year KTBs - we find that the negative impacts of foreign investors on liquidity are stronger for the short-term bonds (3-year KTBs), while those of insurance companies/pension funds and banks on liquidity is stronger for 5-year KTBs. On the other hand, bond holdings by financial investment companies enhance liquidity regardless of bond maturity, but the liquidity-enhancing effect of banks is strong for 3-year and 10-year KTBs. The results indicate that the effect of bond holdings by domestic banks and insurance companies/pension funds on liquidity varies with issuance maturities.

We also conduct the same regression analyses after dividing the sample into the crisis period and post-crisis period and find that the liquidity-reducing effects of foreign investors and liquidity-enhancing effects of financial investment companies are especially strong in the post-crisis period. Additionally, this paper reports that the liquidity-reducing effects of foreign investors are stronger for off-the-runs than on-the-runs. Lastly, our main results are robust when using alternative panel regression models such as the GMM and the pooled OLS with the Newey-West adjusted standard errors for our estimation.

In summary, we provide evidence that foreign investors appear to worsen liquidity while financial investment companies tend to improve liquidity, indicating that heterogeneous institutional investors who participate in trading with different trading strategies or objectives play different roles in the Korean government bond market. 


\section{References}

Amihud, Y. and Mendelson, H. (1986), Asset Pricing and the Bid-ask Spread, Journal of financial Economics, Vol. 17(2), pp. 223-249.

Amihud, Y. (2002), Illiquidity and Stock Returns: Cross-section and Time-series Effects, Journal of Financial Markets, Vol. 5, pp. 31-56.

Amihud, Y., Mendelson, H., (1991), Liquidity, Maturity, and the Yields on U.S. Treasury Securities, Journal of Finance, Vol. 46, pp. 1411-1425

Arellano, M. and Bond, S. (1991), Some Tests of Specification for Panel Data: Monte Carlo Evidence and an Application to Employment Equations, Review of Economic Studies, Vol. 58(2), pp. 277-297.

Balduzzi, P., Elton, E.J. and Green, T.C. (2001), Economic News and Bond Prices: Evidence from the US Treasury Market, Journal of financial and Quantitative Analysis, Vol. 36(4), pp. 523-543.

Beber, A., M. W. Brandt, and K. A. Kavajecz (2009), Flight-to-Quality or Flight-to- Liquidity? Evidence from Euro-Area Bond Market, Review of Financial Studies, Vol. 22, pp. 925-957.

Biais, B. and Green, R.C. (2005), The Microstructure of the Bond Market in the 20th Century, Tepper School of Business.

Booth, G. G., Gurun, U. G., and Zhang, H. (2014), Financial Networks and Trading in Bond Markets, Journal of Financial Markets, Vol. 18, pp. 126-157.

Brandt, M. W., and Kavajecz, K. A. (2004), Price Discovery in the US Treasury Market: The Impact of Order Flow and Liquidity on the Yield Curve, Journal of Finance, Vol. 59(6), pp. 2623-2654.

Brockman P. D. Y. Chung and X. Yan (2009), Block Ownership, Trading Activity, and Market Liquidity," Journal of Financial and Quantitative Analysis, Vol. 44, Issue 6, pp. 1403-1426

Brunnermeier, M. K., and L. H. Pedersen (2009), "Market Liquidity and Funding Liquidity," Review of Financial Studies, Vol. 22, pp. 2201-2238. 
CGFS (2016), Fixed Income Market Liquidity, CGFS papers No. 55, Committee on the Global Financial System.

Choe, H., Kho, B. C., and Stulz, R. M. (1999), Do Foreign Investors Destabilize Stock Markets? The Korean Experience in 1997, Journal of Financial Economics, Vol. 54(2), pp. 227-264.

Choe, H., Kho, B.C., and Stulz, R. (2005), Do Domestic Investors Have an Edge? The Trading Experience of Foreign Investors in Korea, Review of Financial Studies, Vol. 18, pp. 795-829.

Chung, K. and Zhang, H. (2014), A Simple Approximation of Intraday Spreads Using Daily Data, Journal of Financial Markets, Vol. 17, pp. 94-120.

Copeland, T.E. and Galai, D. (1983), Information Effects on the Bid-ask Spread, Journal of Finance, Vol. 38(5), pp. 1457-1469.

Corwin, S.A. and Schultz, P. (2012), A Simple Way to Estimate Bid-ask Spreads from Daily High and Low Prices, Journal of Finance, Vol. 67(2), pp. 719-760.

Dahlquist, M. and Robertsson, G. (2004), A Note on Foreigners' Trading and Price Effects across Firms, Journal of Banking \& Finance, Vol. 28(3), pp. 615-632.

De Jong, F. and Driessen, J. (2005), Liquidity Risk Premia in Corporate Bond Markets, Quarterly Journal of Finance, Vol. 2(2)

Díaz, A. and Escribano, A. (2017), Liquidity Measures throughout the Lifetime of the US Treasury Bond, Journal of Financial Markets, Vol. 33, pp. 42-74.

Díaz, A., Merrick, J.J. and Navarro, E. (2006), Spanish Treasury Bond Market Liquidity and Volatility Pre-and Post-European Monetary Union, Journal of Banking \& Finance, Vol. 30(4), pp. 1309-1332.

Easley, D. and O'hara, M. (1987), Price, Trade Size, and Information in Securities Markets, Journal of Financial Economics, Vol. 19(1), pp. 69-90.

Ejsing, J. W., Sihvonen, J. (2009), Liquidity Premia in German Government Bonds, Working Paper No. 1081, European Central Bank. 
Eleswarapu, V. R., Venkataraman, K. (2006), The Impact of Legal and Political Institutions on Equity Trading Costs: A Cross-country Analysis, Review of Financial Studies, Vol. 19, pp. 1081-1111.

Fama, E.F. and R.R. Bliss (1987), The Information in Long-maturity Forward Rates, American Economic Review, Vol. 77(4), pp. 680-692

Fleming, M. (2003), Measuring Treasury Market Liquidity, Economic Policy Review, Vol. 9, pp. 83-108.

Froot, K.A., O'connell, P.G. and Seasholes, M.S. (2001), The Portfolio Flows of International Investors, Journal of Financial Economics, Vol. 59(2), pp. 151-193.

Glosten, L.R. and Milgrom, P.R. (1985), Bid, Ask and Transaction Prices in a Specialist Market with Heterogeneously Informed Traders, Journal of Financial Economics, Vol. 14(1), pp. 71-100.

Goldreich, D., Hanke, B., Nath, P. (2005), The Price of Future Liquidity: Time-varying Liquidity in the U.S. Treasury Market, Review of Finance, Vol. 9, pp. 1-32.

Goyenko, R.Y., Holden, C.W. and Trzcinka, C.A. (2009), Do Liquidity Measures Measure Liquidity? Journal of financial Economics, Vol. 92(2), pp. 153-181.

Goyenko, R. and Sarkissian, S. (2014), Treasury Bond Illiquidity and Global Equity Returns, Journal of Financial and Quantitative Analysis, Vol. 49(5-6), pp. 1227-1253.

Goyenko, R., Subrahmanyam, A. and Ukhov, A. (2011), "The Term Structure of Bond Market Liquidity and Its Implications for Expected Bond Returns," Journal of Financial and Quantitative Analysis, Vol. 46(1), pp. 111-139.

Green, T.C. (2004), "Economic News and the Impact of Trading on Bond Prices," Journal of Finance, Vol. 59(3), pp. 1201-1233.

Grinblatt, M. and Keloharju, M. (2000), "The Investment Behavior and Performance of Various Investor Types: A Study of Finland's Unique Data Set," Journal of Financial Economics, Vol. 55(1), pp. 43-67. 
Grossman, S.J. and Stiglitz, J.E. (1980), "On the Impossibility of Informationally Efficient Markets," American Economic Review, Vol. 70(3), pp. 393-408.

Hasbrouck, J. (2004), "Liquidity in the Futures Pits: Inferring Market Dynamics from Incomplete Data," Journal of Financial and Quantitative Analysis, Vol. 39, pp. 305-326.

Hasbrouck, J. (2009), "Trading Costs and Returns for US Equities: Estimating Effective Costs from Daily Data," Journal of Finance, Vol. 46, pp. 1445-1477.

Hausman, J.A. (1978), "Specification Tests in Econometrics," Econometrica: Journal of the Econometric Society, pp.1251-1271.

Hendershott, T., Jones, C. M., \& Menkveld, A. J. (2011), "Does Algorithmic Trading Improve Liquidity?” Journal of Finance, Vol. 66(1), pp. 1-33.

Hoskisson R.E., M.A. Hitt, R.A. Johnson, W. Grossman (2000), “Conflicting Voices: The Effects of Institutional Ownership Heterogeneity and Internal Governance on Corporate Innovation Strategies," Academy of Management Journal, Vol. 45, pp. 697-716.

Judson, R.A. and Owen, A.L. (1999), "Estimating Dynamic Panel Data Models: A Guide for Macroeconomists," Economics Letters, Vol. 65(1), pp. 9-15.

Khorana, A., Servaes, H., and Tufano, P. (2005), "Explaining the Size of the Mutual Fund Industry around the World," Journal of Financial Economics, Vol. 78(1), pp. 145-185.

Kyle, A. (1985), "Continuous Auctions and Insider Trading," Econometrica, Vol. 53, pp. 1315-1335.

Lee, J. and Chung, K.H. (2018), "Foreign Ownership and Stock Market Liquidity, International Review of Economics and Finance, Forthcoming.

Li, H., Wang, J., Wu, C. and He, Y. (2009), "Are Liquidity and Information Risks Priced in the Treasury Bond Market?" Journal of Finance, Vol. 64(1), pp. 467-503.

Longstaff, F. (2004), "The Flight-to-Liquidity Premium in U.S. Treasury Bond Prices," Journal of Business, Vol. 77, pp. 511-526. 
Lyons, R. K. (2001), "The Microstructure Approach to Exchange Rates," MIT Press.

Ministry of Strategy and Finance (2016), Korea Treasury Bonds 2016.

Newey, W. and West, K. (1987), "A Simple, Positive Semi-definite, Heteroskedasticity and Autocorrelation Consistent Covariance Matrix," Econometrica, Vol. 55, pp. 703-708.

Nickell, S. (1981), "Biases in Dynamic Models with Fixed Effects," Econometrica, Vol. 49, pp. 1399-1416.

Pasquariello, P. and Vega, C. (2009), "The On-the-run Liquidity Phenomenon," Journal of Financial Economics, Vol. 92(1), pp. 1-24.

Rhee, S. G., Wang, J. (2009), "Foreign Institutional Ownership and Stock Market Liquidity: Evidence from Indonesia," Journal of Banking and Finance, Vol. 33, pp. 1312-1324.

Roll R. (1984), "A Simple Implicit Measure of the Effective Bid-ask Spread in an Efficient Marke,". Journal of Finance, Vol. 39(4), pp. 1127-39

Roodman, D. (2006), "How to Do Xtabond2: An Introduction to 'Difference' and 'System,' GMM in Stata," Center for Global Development Working Paper No. 103.

Rubin, A., (2007), "Ownership Level, Ownership Concentration and Liquidity," Journal of Financial Markets, Vol. 10(3), pp. 219-248.

Schestag, R., Schuster, P. and Uhrig-Homburg, M. (2016), "Measuring Liquidity in Bond Markets," Review of Financial Studies, Vol. 29(5), pp. 1170-1219.

Stoll, H.R. (2000), "Presidential Address: Friction," Journal of Finance, Vol. 55(4), pp. 1479-1514.

Tihanyi, L., R.A. Johnson, R.E. Hoskisson, M.A. Hitt. (2003), "Institutional Ownership Differences and International Diversification: The Effects of Boards of Directors and Technological Opportunity," Academy of Management Journal, Vol. 46, pp. 195-211. 


\section{Appendix}

\section{Variable Descriptions}

Variable

Definition and Measurement

Liquidity measures

Log of the Amihud measure (illiquidity proxy) for bond $\mathrm{i}$ in month $\mathrm{t}$, computed as AMli,j=1/D[|RETi,t|/TVi,t]*109,

LOG(AMI) where RETi,t is bondi' $s$ return on day j and TVi,j is bond i' $s$ trading volume(in KRW) on day j. LOG(AMI) is calculated as the monthly average of the dailyseries.

Log of the market share (liquidity proxy) for bond $i$ in month $t$, computed

LOG(MS) as trading volume for bond $\mathrm{i}$ on day $\mathrm{j}$ divided by the total trading volume in the government bond markets on day j. LOG(MS) is calculated as the monthly average of the daily series.

Bondholding variables

FOREIGNER

Bond holding by foreign investors, computed by the number of OTC shares that are held by foreign institutional investors divided by the number of total outstanding shares for bond $i$ on month $t$

BANK

Bond holding by banks, computed by the number of OTC shares that are held by banks divided by the number of total outstanding shares for bond i on month $t$

Bond holding by insurance companies/pension funds, computed by the

INS\&PEN number of OTC shares that are held by insurance companies and pension funds divided by the number of total outstanding shares for bond $i$ on month $t$

Bond holding by financial investment companies, computed by the number

$\mathrm{Fl}$ of OTC shares that are held by financial companies (e.g., security companies, investment trusts) divided by the number of total outstanding shares for bond $\mathrm{i}$ on month $\mathrm{t}$

Macroeconomic variables

CREDIT RISK

Credit spread, computed by the spread between BB- yield and AA-yield

LEVEL 3-year Treasury yield

SLOPE

The difference between 7- and the 3-year Treasury yield.

CURVATURE

The difference between the 5-year Treasury yield and the average

STKRET difference between the 7- and the 3-year Treasury yields

Stock market return calculated as log(KOSPIt)-log(KOSPIt-1) 
VIX

U.S market uncertainty calculated as $\log (\mathrm{VIXt})-\log (\mathrm{VIXt}-1)$ where $\mathrm{VIX}$ is the Chicago Board Option Exchange (CBOE) market volatility index

AAA-T3

Proxy for flights-to-liquidity and flights-to-quality, computed by the spread between AAA yield and the 3-year Treasury bond yield.

T5KO-T5US

Computed by spread between the 5-year Korean Treasury bond yield and the 5-year U.S Treasury bond yield

FXRATE

Foreign exchange rate calculated as $\log (\mathrm{USD} / \mathrm{KRWt})-\log (\mathrm{USD} / \mathrm{KRWt}-1)$

BASERATE

The Bank of Korea base rate or the reference policy rate

\section{Bond characteristic variables}

AGE The age of the bond in months

ON Dummy variables that take value one if the status of the bond is on-the-run.

LOG(OUTSHR) Log of the amount of outstanding shares (in KRW)

BONDRET Bond return calculated as $\log ($ PRCit)-log(PRCit-1) 


\section{$<$ Abstract in Korean>}

\section{투자자별 보유지분과 국고채 시장의 유동성}

\section{이지은*}

본고는 투자자별 보유지분이 국고채 시장의 유동성에 미치는 영향을 2007년 부터 2016년 간 장외에서 거래되는 개별 국고채권 거래데이터를 활용하여 분석 하였다. 분석결과, 외국인 보유지분이 증가할수록 가격충격이 확대되고, 거래활 동이 축소되면서 유동성이 저하되었다. 특히, 외국인이 유동성에 미치는 부정적 영향은 지표물보다 경과물 보유 시, 금융위기 시(2007-2009년)보다 위기 이후 (2010-2016년)에 더욱 강화되었다. 반면, 국내 금융투자사의 채권보유비중이 증 가할수록 유동성이 개선되었으며, 그 외 보험 및 연기금과 은행의 보유지분이 유 동성에 미치는 영향은 발행만기별로 상이하였다.

핵심 주제어: 외국인 투자자, 기관투자자, 투자자별 다양성, 국고채 유동성

JEL Classification: G10, G32, G34

\footnotetext{
* 한국은행 경제연구원 미시제도연구실 부연구위원 (전화: 02-759-5470, E-mail: jelee@bok.or.kr)
} 


\section{$\mathrm{BOK}$ 경제연구 발간목록}

한국은행 경제연구원에서는 Working Paper인 『BOK 경제연구』를 수시로 발간하고 있습니다. ${ }^{『} \mathrm{BOK}$ 경제연구』는 주요 경제 현상 및 정책 효과에 대한 직관적 설명 뿐 아니라 깊이 있는 이론 또는 실증 분석을 제공함으로써 엄밀한 논증에 초점을 두는 학술논문 형태의 연구이며 한국은행 직원 및 한국은행 연구용역사업의 연구 결과물이 수록되고 있습니다.

『BOK 경제연구』는 한국은행 경제연구원 홈페이지(http://imer.bok.or.kr)에서 다운로드하여 보실 수 있습니다.

\section{제2014-1 Network Indicators for Monitoring} Intraday Liquidity in BOK-Wire+

2 중소기업에 대한 신용정책 효과

3 경제충격 효과의 산업간 공행성 분석

4 서비스업 발전을 통한 내외수 균형성장: 기대효과 및 리스크

5 Cross-country-heterogeneous and Time-varying Effects of Unconventional Monetary Policies in AEs on Portfolio Inflows to EMEs

6 인터넷뱅킹, 결제성예금 및 은행 수익성과의 관계 분석

7 Dissecting Foreign Bank Lending Behavior During the 2008-2009 Crisis

8 The Impact of Foreign Banks on Monetary Policy Transmission during the Global Financial Crisis of 2008-2009: Evidence from Korea

9 Welfare Cost of Business Cycles in Economies with Individual Consumption Risk

10 Investor Trading Behavior Around the Time of Geopolitical Risk Events: Evidence from South Korea

11 Imported-Inputs Channel of Exchange Rate Pass-Through: Evidence from Korean Firm-Level Pricing Survey
Seungjin Baek •

Kimmo Soram ki • Jaeho Yoon

정호성·임호성

황선웅 - 민성환 ·

신동현·김기호

김승원 · 황광명

Kyoungsoo Yoon •

Christophe Hurlin

이동규·전봉걸

Moon Jung Choi •

Eva Gutierrez •

Maria Soledad Martinez Peria

Bang Nam Jeon •

Hosung Lim $\cdot$ Ji Wu

Martin Ellison •

Thomas J. Sargent

Young Han Kim •

Hosung Jung

Jae Bin Ahn •

Chang-Gui Park 


\begin{tabular}{|c|c|c|}
\hline 제2014-12 & 비대칭 금리기간구조에 대한 실증분석 & 김기호 \\
\hline 13 & $\begin{array}{l}\text { The Effects of Globalization } \\
\text { on Macroeconomic Dynamics } \\
\text { in a Trade-Dependent Economy: } \\
\text { the Case of Korea }\end{array}$ & Fabio Milani · Sung Ho Park \\
\hline 14 & $\begin{array}{l}\text { 국제 포트폴리오투자 행태 분석: 채권-주식 } \\
\text { 투자자금간 상호관계를 중심으로 }\end{array}$ & 이주용·김근영 \\
\hline 15 & $\begin{array}{l}\text { 북한 경제의 추격 성장 가능성과 } \\
\text { 정책 선택 시나리오 }\end{array}$ & 이근 · 최지영 \\
\hline 16 & $\begin{array}{l}\text { Mapping Korea's International Linkages } \\
\text { using Generalised Connectedness Measures }\end{array}$ & Hail Park $\cdot$ Yongcheol Shin \\
\hline 17 & $\begin{array}{l}\text { 국제자본이동 하에서 환율신축성과 } \\
\text { 경상수지 조정: 국가패널 분석 }\end{array}$ & 김근영 \\
\hline 18 & $\begin{array}{l}\text { 외국인 투자자가 외환시장과 주식시장 간 } \\
\text { 유동성 동행화에 미치는 영향 }\end{array}$ & 김준한 $\cdot$ 이지은 \\
\hline 19 & $\begin{array}{l}\text { Forecasting the Term Structure } \\
\text { of Government Bond Yields } \\
\text { Using Credit Spreads and Structural Breaks }\end{array}$ & $\begin{array}{l}\text { Azamat Abdymomunov } \\
\text { Kyu Ho Kang } \\
\text { Ki Jeong Kim }\end{array}$ \\
\hline 20 & $\begin{array}{l}\text { Impact of Demographic Change } \\
\text { upon the Sustainability of Fiscal Policy }\end{array}$ & $\begin{array}{l}\text { Younggak Kim· } \\
\text { Myoung Chul Kim } \\
\text { Seongyong Im }\end{array}$ \\
\hline 21 & $\begin{array}{l}\text { The Impact of Population Aging } \\
\text { on the Countercyclical Fiscal Stance in Korea, } \\
\text { with a Focus on the Automatic Stabilizer }\end{array}$ & $\begin{array}{l}\text { Tae-Jeong Kim } \cdot \\
\text { Mihye Lee } \cdot \text { Robert Dekle }\end{array}$ \\
\hline 22 & $\begin{array}{l}\text { 미 연준과 유럽중앙은행의 비전통적 통화정책 } \\
\text { 수행원칙에 관한 고찰 }\end{array}$ & 김병기· 김진일 \\
\hline 23 & $\begin{array}{l}\text { 우리나라 일반인의 인플레이션 기대 형성 } \\
\text { 행태 분석 }\end{array}$ & 이한규·최진호 \\
\hline
\end{tabular}


제2014-24 Nonlinearity in Nexus between

Working Hours and Productivity

25 Strategies for Reforming Korea's Labor Market to Foster Growth

26 글로벌 금융위기 이후 성장잠재력 확충: 2014 한국은행 국제컨퍼런스 결과보고서

27 인구구조 변화가 경제성장률에 미치는 영향: 자본이동의 역할에 대한 논의를 중심으로

28 Safe Assets

29 확장된 실업지표를 이용한 우리나라 노동시장에서의 이력현상 분석

Entropy of Global Financial Linkages

31 International Currencies Past, Present and Future: Two Views from Economic History

32 금융체제 이행 및 통합 사례:

남북한 금융통합에 대한 시사점

Measuring Price-Level Uncertainty and Instability in the U.S., 1850-2012

고용보호제도가 노동시장 이원화

및 노동생산성에 미치는 영향

35 해외충격시 외화예금의 역할 : 주요 신흥국 신용스프레드에 미치는 영향을 중심으로 Emerging Market Economies, and Their Policy Responses
Dongyeol Lee •

Hyunjoon Lim

Mai Dao · Davide Furceri ·

Jisoo Hwang .

Meeyeon Kim •

Tae-Jeong Kim

한국은행 경제연구원

손종칠

Robert J. Barro

김현학 · 황광명

Daeyup Lee

Barry Eichengreen

김병연

Timothy Cogley •

Thomas J. Sargent

김승원

정호성 - 우준명

김인수 · 이명수

황광명 · 김경민 ·

노충식·김미진

Woon Gyu Choi •

Taesu Kang •

Geun-Young Kim •

Byongju Lee 
제2015-1 글로벌 금융위기 이후 주요국

통화정책 운영체계의 변화

2 미국 장기시장금리 변동이 우리나라 금리기간구조에 미치는 영향 분석 및 정책적 시사점

3 직간접 무역연계성을 통한 해외충격의 우리나라 수출입 파급효과 분석

4 통화정책 효과의 지역적 차이

5 수입중간재의 비용효과를 고려한 환율변동과 수출가격 간의 관계

6 중앙은행의 정책금리 발표가 주식시장 유동성에 미치는 영향

7 은행 건전성지표의 변동요인과 거시건전성 규제의 영향

8 Price Discovery and Foreign Participation in The Republic of Korea's Government Bond Futures and Cash Markets

9 규제가 노동생산성에 미치는 영향:

한국의 산업패널 자료를 이용한 실증분석

10 인구 고령화와 정년연장 연구

(세대 간 중첩모형(OLG)을 이용한 정량 분석)

11 예측조합 및 밀도함수에 의한 소비자물가 상승률 전망

12 인플레이션 동학과 통화정책

13 Failure Risk and the Cross-Section of Hedge Fund Returns

14 Global Liquidity and Commodity Prices

15 Foreign Ownership, Legal System and Stock Market Liquidity
김병기·김인수

강규호·오형석

최문정·김근영

김기호

김경민

이지은

강종구

Jaehun Choi - Hosung Lim •

Rogelio Jr. Mercado •

Cyn-Young Park

이동렬· 최종일·이종한

홍재화 - 강태수

김현학

우준명

Jung-Min Kim

Hyunju Kang •

Bok-Keun $\mathrm{Yu}$.

Jongmin $\mathrm{Yu}$

Jieun Lee $\cdot$ Kee H. Chung 
제2015-16 바젤피 은행 경기대응완충자본 규제의 기준지표에 대한 연구

17 우리나라 대출 수요와 공급의 변동요인 분석

18 북한 인구구조의 변화 추이와 시사점

19 Entry of Non-financial Firms and Competition in the Retail Payments Market

20 Monetary Policy Regime Change and Regional Inflation Dynamics: Looking through the Lens of Sector-Level Data for Korea

21 Costs of Foreign Capital Flows in Emerging Market Economies: Unexpected Economic Growth and Increased Financial Market Volatility

22 글로벌 금리 정상화와 통화정책 과제: 2015년 한국은행 국제컨퍼런스 결과보고서

23 The Effects of Global Liquidity on Global Imbalances

24 실물경기를 고려한 내재 유동성 측정

25 Deflation and Monetary Policy

26 Macroeconomic Shocks and Dynamics of Labor Markets in Korea

27 Reference Rates and Monetary Policy Effectiveness in Korea

29 An Analysis of Trade Patterns in East Asia and the Effects of the Real Exchange Rate Movements

30 Forecasting Financial Stress Indices in Korea: A Factor Model Approach
서현덕·이정연

강종구 · 임호성

최지영

Jooyong Jun

Chi-Young Choi •

Joo Yong Lee

Roisin O'Sullivan

Kyoungsoo Yoon • Jayoung Kim

한국은행 경제연구원

Marie-Louise DJIGBENOU-KRE •

Hail Park

우준명·이지은

Barry Eichengreen

Tae Bong Kim •

Hangyu Lee

Heung Soon Jung •

Dong Jin Lee.

Tae Hyo Gwon .

Se Jin Yun

Bongseok Choi •

Wooyoung Park.

Bok-Keun Yu

Moon Jung Choi

Geun-Young Kim • Joo Yong Lee

Hyeongwoo Kim $\cdot$ Hyun Hak Kim. Wen Shi 


\begin{tabular}{|c|c|c|}
\hline 제2016 -1 & $\begin{array}{l}\text { The Spillover Effects of U.S. Monetary } \\
\text { Policy on Emerging Market Economies: } \\
\text { Breaks, Asymmetries and Fundamentals }\end{array}$ & $\begin{array}{l}\text { Geun-Young Kim } \cdot \\
\text { Hail Park } \\
\text { Peter Tillmann }\end{array}$ \\
\hline 2 & $\begin{array}{l}\text { Pass-Through of Imported Input Prices to } \\
\text { Domestic Producer Prices: Evidence from } \\
\text { Sector-Level Data }\end{array}$ & $\begin{array}{l}\text { JaeBin Ahn } \\
\text { Chang-Gui Park } \\
\text { Chanho Park }\end{array}$ \\
\hline 3 & $\begin{array}{l}\text { Spillovers from U.S. Unconventional } \\
\text { Monetary Policy and Its Normalization } \\
\text { to Emerging Markets: A Capital Flow } \\
\text { Perspective }\end{array}$ & $\begin{array}{l}\text { Sangwon Suh } \\
\text { Byung-Soo Koo }\end{array}$ \\
\hline 4 & $\begin{array}{l}\text { Stock Returns and Mutual Fund Flows } \\
\text { in the Korean Financial Market: } \\
\text { A System Approach }\end{array}$ & $\begin{array}{l}\text { Jaebeom Kim } \\
\text { Jung-Min Kim }\end{array}$ \\
\hline 5 & $\begin{array}{l}\text { 정책금리 변동이 성별·세대별 고용률에 } \\
\text { 미치는 영향 }\end{array}$ & 정성엽 \\
\hline 6 & $\begin{array}{l}\text { From Firm-level Imports to } \\
\text { Aggregate Productivity: Evidence } \\
\text { from Korean Manufacturing Firms Data }\end{array}$ & $\begin{array}{l}\text { JaeBin Ahn } \\
\text { Moon Jung Choi }\end{array}$ \\
\hline 7 & $\begin{array}{l}\text { 자유무역협정(FTA)이 한국 기업의 } \\
\text { 기업내 무역에 미친 효과 }\end{array}$ & 전봉걸 · 김은숙 $\cdot$ 이주용 \\
\hline 8 & $\begin{array}{l}\text { The Relation Between Monetary and } \\
\text { Macroprudential Policy }\end{array}$ & Jong Ku Kang \\
\hline 9 & $\begin{array}{l}\text { 조세피난처 투자자가 투자 기업 및 주식 } \\
\text { 시장에 미치는 영향 }\end{array}$ & 정호성 · 김순호 \\
\hline 10 & $\begin{array}{l}\text { 주택실거래 자료를 이용한 주택부문 거시 } \\
\text { 건전성 정책 효과 분석 }\end{array}$ & 정호성·이지은 \\
\hline 11 & $\begin{array}{l}\text { Does Intra-Regional Trade Matter in } \\
\text { Regional Stock Markets?: New Evidence } \\
\text { from Asia-Pacific Region }\end{array}$ & $\begin{array}{l}\text { Sei-Wan Kim } \cdot \\
\text { Moon Jung Choi }\end{array}$ \\
\hline 12 & $\begin{array}{l}\text { Liability, Information, and Anti-fraud } \\
\text { Investment in a Layered Retail } \\
\text { Payment Structure }\end{array}$ & $\begin{array}{l}\text { Kyoung-Soo Yoon } \\
\text { Jooyong Jun }\end{array}$ \\
\hline 13 & $\begin{array}{l}\text { Testing the Labor Market Dualism in } \\
\text { Korea }\end{array}$ & $\begin{array}{l}\text { Sungyup Chung } \\
\text { Sunyoung Jung }\end{array}$ \\
\hline 14 & $\begin{array}{l}\text { 북한 이중경제 사회계정행렬 추정을 통한 } \\
\text { 비공식부문 분석 }\end{array}$ & 최지영 \\
\hline
\end{tabular}




\begin{tabular}{|c|c|c|}
\hline \multirow[t]{2}{*}{ 제2016 -15 } & $\begin{array}{l}\text { Divergent EME Responses to Global and } \\
\text { Domestic Monetary Policy Shocks }\end{array}$ & $\begin{array}{l}\text { Woon Gyu Choi · } \\
\text { Byongju Lee • } \\
\text { Taesu Kang • } \\
\text { Geun-Young Kim }\end{array}$ \\
\hline & $\begin{array}{l}\text { Loan Rate Differences across Financial } \\
\text { Sectors: A Mechanism Design } \\
\text { Approach }\end{array}$ & $\begin{array}{l}\text { Byoung-Ki Kim } \\
\text { Jun Gyu Min }\end{array}$ \\
\hline 17 & $\begin{array}{l}\text { 근로자의 고용형태가 임금 및 소득 분포에 } \\
\text { 미치는 영향 }\end{array}$ & 최충·정성엽 \\
\hline 18 & Endogeneity of Inflation Target & $\begin{array}{l}\text { Soyoung Kim • } \\
\text { Geunhyung Yim }\end{array}$ \\
\hline 19 & $\begin{array}{l}\text { Who Are the First Users of a } \\
\text { Newly-Emerging International } \\
\text { Currency? A Demand-Side Study of } \\
\text { Chinese Renminbi Internationalization }\end{array}$ & $\begin{array}{l}\text { Hyoung-kyu Chey } \\
\text { Geun-Young Kim• } \\
\text { Dong Hyun Lee }\end{array}$ \\
\hline 20 & $\begin{array}{l}\text { 기업 취약성 지수 개발 및 기업 부실화에 } \\
\text { 대한 영향 분석 }\end{array}$ & 최영준 \\
\hline 21 & $\begin{array}{l}\text { US Interest Rate Policy Spillover and } \\
\text { International Capital Flow: Evidence from } \\
\text { Korea }\end{array}$ & $\begin{array}{l}\text { Jieun Lee } \cdot \\
\text { Jung-Min Kim } \\
\text { Jong Kook Shin }\end{array}$ \\
\hline \multirow{4}{*}{$\begin{array}{r}\text { 제2017 -1 } \\
2\end{array}$} & $\begin{array}{l}\text { 가계부채가 소비와 경제성장에 미치는 영향 } \\
\text { - 유량효과와 저량효과 분석 - }\end{array}$ & 강종구 \\
\hline & $\begin{array}{l}\text { Which Monetary Shocks Matter in } \\
\text { Small Open Economies? Evidence } \\
\text { from SVARs }\end{array}$ & $\begin{array}{l}\text { Jongrim } \mathrm{Ha} \cdot \\
\text { Inhwan So }\end{array}$ \\
\hline & FTA의 물가 안정화 효과 분석 & 곽노선·임호성 \\
\hline & $\begin{array}{l}\text { The Effect of Labor Market } \\
\text { Polarization on the College } \\
\text { Students' Employment }\end{array}$ & Sungyup Chung \\
\hline 5 & 국내 자영업의 폐업률 결정요인 분석 & 남윤미 \\
\hline 6 & $\begin{array}{l}\text { 차주별 패널자료를 이용한 주택담보대출의 } \\
\text { 연체요인에 대한 연구 }\end{array}$ & 정호성 \\
\hline 7 & $\begin{array}{l}\text { 국면전환 확산과정모형을 이용한 콜금리 } \\
\text { 행태 분석 }\end{array}$ & 최승문·김병국 \\
\hline
\end{tabular}




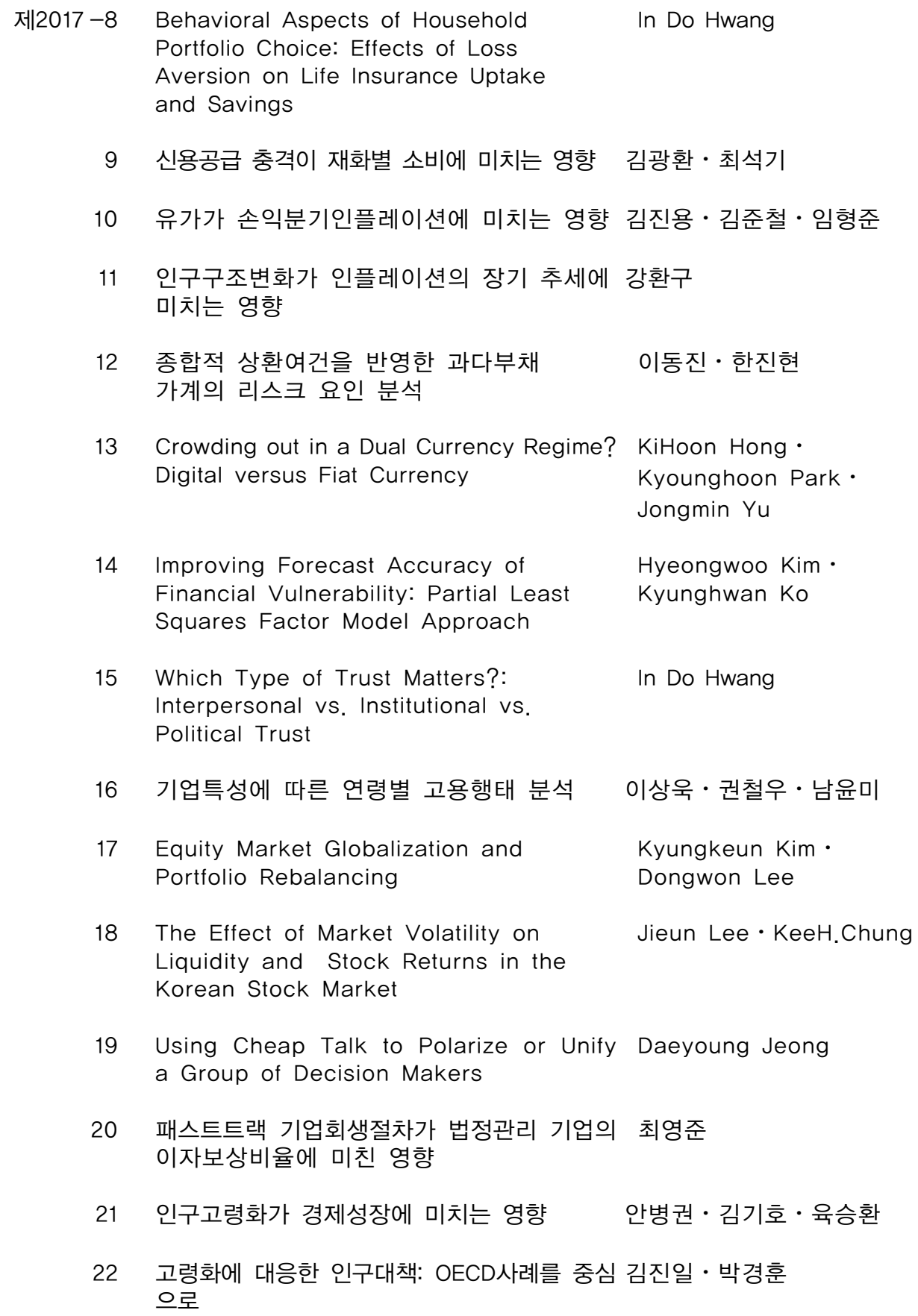

12 종합적 상환여건을 반영한 과다부채 가계의 리스크 요인 분석

이동진 · 한진현

13 Crowding out in a Dual Currency Regime? Digital versus Fiat Currency

KiHoon Hong • Kyounghoon Park • Jongmin $\mathrm{Yu}$

14 Improving Forecast Accuracy of Hyeongwoo Kim • Financial Vulnerability: Partial Least Squares Factor Model Approach

15 Which Type of Trust Matters?: Interpersonal vs. Institutional vs. Kyunghwan Ko

In Do Hwang Political Trust

16 기업특성에 따른 연령별 고용행태 분석 이상욱-권철우·남윤미

17 Equity Market Globalization and Portfolio Rebalancing

Kyungkeun Kim • Dongwon Lee

18 The Effect of Market Volatility on Jieun Lee $\cdot \mathrm{KeeH}$.Chung Liquidity and Stock Returns in the Korean Stock Market

19 Using Cheap Talk to Polarize or Unify Daeyoung Jeong a Group of Decision Makers

20 패스트트랙 기업회생절차가 법정관리 기업의 최영준 이자보상비율에 미친 영향

21 인구고령화가 경제성장에 미치는 영향 안병권·김기호·육승환

22 고령화에 대응한 인구대책: OECD사례를 중심 김진일·박경훈 으로 
제2017-23 인구구조변화와 경상수지

24 통일과 고령화

25 인구고령화가 주택시장에 미치는 영향

26 고령화가 대외투자에 미치는 영향

27 인구고령화가 가계의 자산 및 부채에 미치는 영향

28 인구고령화에 따른 우리나라 산업구조 변화

29 인구구조 변화와 재정

30

31

32

33

Bank Globalization and Monetary

Policy Transmission in Small Open

Economies

34

기존 경영자 관리인(DIP) 제도의 회생기업 경영성과에 대한 영향

35 Transmission of Monetary Policy in Times of High Household Debt

제2018 -1 4차 산업혁명과 한국의 혁신역량:

특허자료를 이용한 국가.기술별 비교 분석, 1976-2015

2 What Drives the Stock Market Comovements between Korea and China, Japan and the US?

3 Who Improves or Worsens Liquidity in the Korean Treasury Bond Market?
김경근 · 김소영

최지영

오강현 · 김솔·윤재준 ·

안상기·권동휘

임진수·김영래

조세형·이용민 · 김정훈

강종구

송호신 · 허준영

이철희 · 이지은

윤경수 - 차재훈 - 박소희 강선영

한재준 · 소인환

Inhwan So

최영준

Youngju Kim •

Hyunjoon Lim

이지홍·임현경·정대영

Jinsoo Lee $\cdot$

Bok-Keun $\mathrm{Yu}$

Jieun Lee 